\title{
THE IRON AGE AROUND THE MEDITERRANEAN: A HIGH CHRONOLOGY PERSPECTIVE FROM THE GRONINGEN RADIOCARBON DATABASE
}

\author{
Johannes van der Plicht $^{1} \bullet$ Hendrik J Bruins ${ }^{2} \bullet$ Albert J Nijboer $^{3}$ \\ ABSTRACT. In this paper, we present an overview of radiocarbon dating contributions from Groningen, concerning 9 sites \\ from around the Mediterranean region: Israel, Sinai (Egypt), Jordan, Spain, Tunisia, and Italy. Full date lists of the 9 sites are \\ presented. Our ${ }^{14} \mathrm{C}$ dates are discussed in terms of present actual chronological debates. We show that all our ${ }^{14} \mathrm{C}$ dates coher- \\ ently support a "high chronology" for the Iron Age in each respective area of the Mediterranean region.
}

\section{INTRODUCTION}

For chronological studies, we strongly favor an individual site approach, in which each archaeological site is treated and evaluated on its own account, both in terms of radiocarbon dates and archaeological context. Such an approach should be transparent in the sense that all ${ }^{14} \mathrm{C}$ dates are duly published in detail, while also the archaeological context of each date is presented in a comprehensive manner. Thus, the Groningen ${ }^{14} \mathrm{C}$ laboratories (AMS and conventional) provided the scientific basis for chronological research concerning the Iron Age in the circum Mediterranean region (Figure 1) at Tel Rehov in northern-central Israel (Bruins et al. 2003, 2005a, 2007; Mazar et al. 2005; van der Plicht and Bruins 2005), at Tel Dan in northern Israel (Bruins et al. 2005b), Tell el-Qudeirat in the northeastern Sinai Desert (Egypt), Horvat Haluqim in the central Negev Desert (Bruins 1986; Bruins and van der Plicht 2004, 2005, 2007), Khirbat-en Nahas in the Arabah Desert in southwestern Jordan (Higham et al. 2005; Levy et al. 2005), Celano in central Italy (Nijboer et al. 1999/2000), Latium Vetus in central Italy (Nijboer et al. 1999/2000), Carthage in Tunisia (Nijboer and van der Plicht 2006, 2008), and Huelva in southwestern Spain (Nijboer and van der Plicht 2006).

The ${ }^{14} \mathrm{C}$ dating results from each of these 9 sites all favor without exception a "High Chronology" for the Iron Age, i.e older than alternative "Low Chronology" viewpoints or older than conventional viewpoints. We present here a review of these dating results in relation to the chronological controversies. Complete date lists are included. Some of these ${ }^{14} \mathrm{C}$ dates have not been published, while others appear in books or conference proceedings, being less accessible as a result. A map indicating the location of the 9 circum Mediterranean sites is shown in Figure 1.

The term "High Chronology" requires some additional explanation in order to define its meaning, as we deal with several areas in the Mediterranean region. Concerning the southern Levant, Mazar (2005) presented an analysis about the development and status of the Iron Age chronological controversies. A central point in this controversy involves the United Monarchy of ancient Israel, i.e. the biblical period of the first 3 kings (Saul, David, and Solomon), as mentioned in biblical sources. The authenticity of the United Monarchy was questioned in some influential archaeological studies (Wightman 1990; Jamieson-Drake 1991). A few years later, Finkelstein (1996) published his own alternative view about the archaeology of the United Monarchy. He suggested the lowering of the entire early Iron Age in the southern Levant (Finkelstein 1995, 1996). Thus, ceramic assemblages associated with the traditional 12th-10th centuries BCE were lowered by about 50-80 yr (Mazar

\footnotetext{
${ }^{1}$ Center for Isotope Research, Groningen University, Groningen. Also: Faculty of Archaeology, Leiden University, Leiden, the Netherlands.

${ }^{2}$ Ben Gurion University of the Negev, Jacob Blaustein Institutes for Desert Research, Sede Boker Campus. Also: Department of Bible, Archaeology, and Ancient Near Eastern Studies, Beer Sheva Campus, Israel.

${ }^{3}$ Institute for Archaeology, Groningen University, Groningen, the Netherlands.
}

(C) 2009 by the Arizona Board of Regents on behalf of the University of Arizona Celebrating 50 Years of Radiocarbon

RADIOCARBON, Vol 51, Nr 1, 2009, p 213-242 


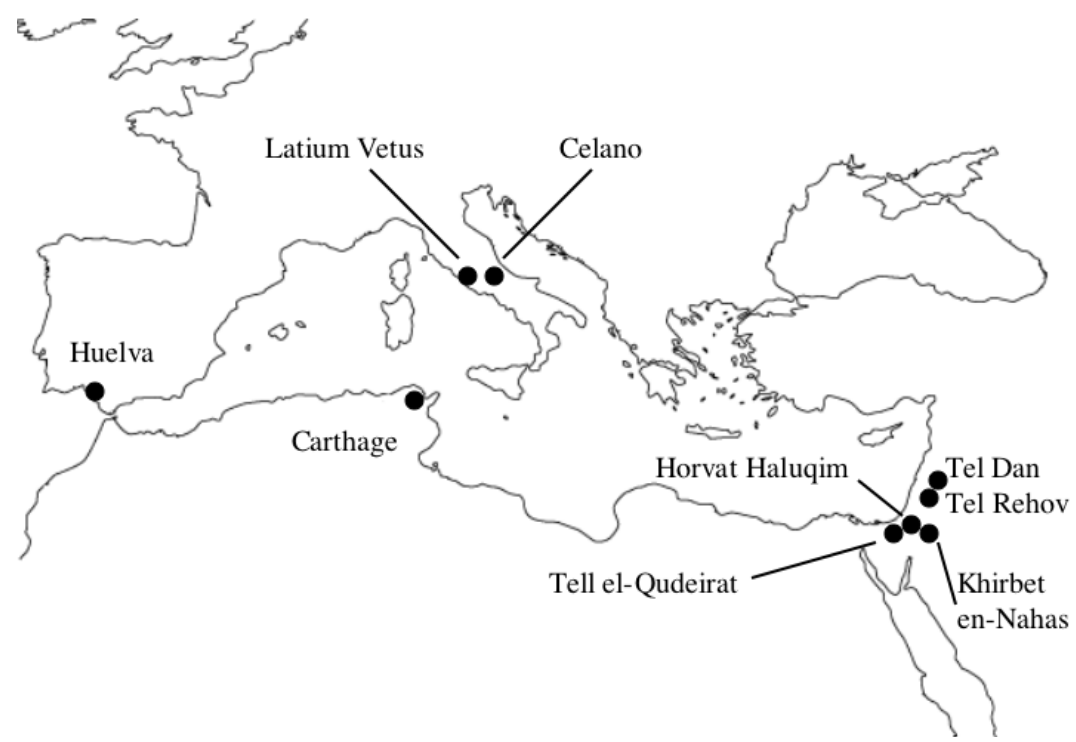

Figure 1 Map of the Mediterranean region, showing the locations of the 9 sites discussed in this paper. For each of these sites, ${ }^{14} \mathrm{C}$ dates are given in archaeological context in the date lists (Tables 1-9).

2005:18). This viewpoint by Finkelstein became known as the Low Chronology, in which traditional late Iron Age I assemblages are suggested to move from the late 11th century to the 10th century BCE, and traditional 10th century assemblages to the 9th century BCE (Mazar 2005:18). This situation is summarized in the following scheme:

\begin{tabular}{lll}
\hline & $\begin{array}{l}\text { Revised Traditional Chronology (BCE) } \\
\text { (Mazar 2005) }\end{array}$ & $\begin{array}{l}\text { Low Chronology (BCE) } \\
\text { (Finkelstein 1995, 1996, 2005; } \\
\text { Finkelstein and Piasetzky 2003) }\end{array}$ \\
\hline Iron Age division Age IA & $1200-1140 / 1130$ & about 50-80 yr lower \\
about 50-80 yr lower \\
Iron Age IB & $1150 / 40-$ about 980 & about 920/900-about 840/830 \\
Iron Age IIa & about 980-about 840/830 & \\
Iron Age IIb & about 840/830-732/701 & \\
Iron Age IIIa & about 732/701-605/586 & \\
Iron Age IIIc & $605 / 586-520$ & \\
\hline
\end{tabular}

Summarizing the numerical difference between the "low chronology" of Finkelstein and his own "revised traditional chronology," Mazar poignantly states: "The difference between us now is merely 60 years for the beginning of the Iron IIA and zero for its end. The difference corresponds to the timeframe traditionally assigned to David and Solomon. Is it a coincidence? I doubt it." (Mazar 2005:23).

The "revised traditional chronology" is supported by the most detailed ${ }^{14} \mathrm{C}$ series (64 dates) for a single site in the Iron Age of the southern Levant: Tel Rehov (Mazar 2003; Bruins et al. 2003, 2005a, 2007; Mazar et al. 2005). However, in this article, we prefer to use the more general term "High Chronology," which is more appropriate in relation to all 9 sites in the Mediterranean region, 
because the term "revised traditional chronology" is specific for ancient Israel. Moreover, High Chronology is the clear antonym of Low Chronology, whether the latter is contra-traditional, traditional, or conventional. The Groningen ${ }^{14} \mathrm{C}$ results of the presented 9 sites (see Figure 1) support in all cases a High Chronology.

\section{RADIOCARBON AFTER 50+ YEARS}

The ${ }^{14} \mathrm{C}$ dating method was developed around 1950 by W F Libby (1908-1980), who received the Nobel Prize for this important discovery (Libby 1952; Berger 1983). Archaeologists outside the Near East adopted ${ }^{14} \mathrm{C}$ dating as a main chronological measuring tool in most cases. The fact that organic matter (fossil bone, charcoal, plants remains, etc.) could be directly ("absolutely") dated by a physical measurement was considered a revolution for archaeology (Renfrew 1999). However, in Near Eastern archaeology, the standard deviations of the ${ }^{14} \mathrm{C}$ dates in the Bronze and Iron ages were considered too large in the early days of ${ }^{14} \mathrm{C}$ dating (typically centuries) in comparison to the perception of more accurate cultural associations with ancient Egyptian and Mesopotamian calendars, based on literary sources (Kenyon 1960; Weinstein 1984). Even as recently as the year $2000,{ }^{14} \mathrm{C}$ dating was not given to play any role in the Iron Age chronology controversy in Israel, as debated in Science (Balter 2000). Since then, the situation has changed. Perhaps this was partly spawned by the 17th International Radiocarbon Conference, held for the first time in Israel, in June 2000, as part of the conference program was dedicated to Near East chronology (Bruins et al. 2001).

${ }^{14} \mathrm{C}$ dating has improved dramatically since the 1950s and 1960s in all practical applications, including archaeology. The precision of the physical measurements improved; a precision of $<2 \%$ o became possible, depending on available sample size and quality (e.g. de Jong et al. 1989). Mass-dependent effects (isotope fractionation) influence the ${ }^{14} \mathrm{C}$ content of samples, and thus their ${ }^{14} \mathrm{C}$ age. These effects became understood and can be corrected for using the content of the stable isotope ${ }^{13} \mathrm{C}$ in the ${ }^{14} \mathrm{C}$-dated sample (e.g. Mook and Streurman 1983). Precise calibration curves are now available going back in time to the last Glacial period (Reimer et al. 2004; Bronk Ramsey et al. 2006). The accelerator mass spectrometry (AMS) method enables dating of small (milligram-size) samples such as seeds, wood from annual tree rings, and precious bones (Tuniz et al. 1998). AMS also introduced large-scale dating programs, sometimes resulting in series of hundreds of dates. Today, tens of thousands of dates are produced annually (albeit not all in the field of archaeology) by laboratories worldwide, which was just unthinkable a few decades ago.

The mutual experience of both ${ }^{14} \mathrm{C}$ scientists and archaeologists led to practical recommendations for sample selection criteria (Mook and Waterbolk 1985; more recently updated by van Strydonck et al. 1999; see also van der Plicht and Bruins 2001 for Near Eastern contexts). These recommendations can be summarized as follows:

1. The sample has to come from a closed archaeological context or secure stratigraphic layer.

2. The sample must represent the event of archaeological interest.

3. The sample ought to come, if possible, from a context with artifacts pertaining to a specific cultural phase.

4. The sample should not be contaminated.

5. Short-lived samples are preferred for ${ }^{14} \mathrm{C}$ dating.

6. More than 1 date per context or phase is recommended.

7. The ${ }^{14} \mathrm{C}$ laboratory must adhere to quality aspects as is common practice by the ${ }^{14} \mathrm{C}$ community (such as organic content and $\delta^{13} \mathrm{C}$ of the sample). 
8. $\mathrm{A}^{14} \mathrm{C}$ date cannot be dissociated from the archaeological context; this means that statistics on sets of dates (like averaging) can only be applied to single archaeological contexts.

9. The ${ }^{14} \mathrm{C}$ dates must be reported according to the convention (i.e. in ${ }^{14} \mathrm{C} \mathrm{yr} \mathrm{BP}$ ), defined as measured relative to the oxalic acid standard, including correction for isotopic fractionation, based on $\delta^{13} \mathrm{C}$ of the sample.

10. The ${ }^{14} \mathrm{C}$ dates are to be calibrated using the most recent calibration curve (at present IntCal04, Reimer et al. 2004), as recommended by the ${ }^{14} \mathrm{C}$ community.

11. Calibrated dates are presented in cal $\mathrm{BC}$ or cal $\mathrm{AD}$ (or equivalents like cal $\mathrm{BP}$, cal $\mathrm{BCE}$, cal CE).

12. The archaeological context and the ${ }^{14} \mathrm{C}$ determination details need to be published together.

13. The ${ }^{14} \mathrm{C}$ laboratory must take part in the internationally organized intercomparison studies.

For detailed discussions concerning the reporting of ${ }^{14} \mathrm{C}$ dates, we refer to Mook and van der Plicht (1999); concerning laboratory intercomparisons, to Scott (2003); for calibration issues, to Reimer et al. (2004) and Bronk Ramsey et al. (2006).

Calibration of ${ }^{14} \mathrm{C}$ dates into calendar years has been named the "second radiocarbon revolution" (Renfrew 1999). A milestone in this second revolution was the publication of the first recommended calibration curves, based on dendrochronologically dated tree-ring series from the United States, Ireland, and Germany (Pearson and Stuiver 1986; Stuiver and Pearson 1986). A typical good ${ }^{14} \mathrm{C}$ date has a $1-\sigma$ measurement error of say 25-30 BP. A very high precision of $15 \mathrm{BP}(1 \sigma)$ can be reached in exceptional cases (like large samples of single-year grains, measured by a large proportional counter; see van der Plicht and Bruins 2005). However, even precise ${ }^{14} \mathrm{C}$ measurements may give calibrated age ranges of about 1 century, due to the wiggles in the calibration curve (see e.g. Figure 2a). However, when a series of dates is available in stratigraphical order, the precision can be improved significantly (see Figure 2b). Such analysis is based on so-called Bayesian statistics, by which in addition to the measurement (the ${ }^{14} \mathrm{C}$ dating of an event), prior information (in this case the sequence of events) is used. Thus, the model selects only part of the single calibrated probability distribution, and the single date calibration (light gray in Figure 2a) can be replaced by a more precise distribution (dark gray in Figure 2b). The technique is a form of "stratified archaeological wiggle matching," based on the principle that "successive layers cannot have the same position on the calibration curve but must follow each other in time" (Bruins et al. 2003:316), as shown in detail for the Tel Rehov series (Bruins et al. 2003, 2005a). The most common program used for this calibration of a series of related events is OxCal (Bronk Ramsey 1995, 2001). The examples shown here (Figure 2) are taken from the manual of this program. For a recent review of chronological deposition models, see Bronk Ramsey (2008).

The potential for obtaining precise chronologies for a high-quality stratigraphic sequence is great. For example, the technique has been applied on a large scale to the Neolithic of Britain. By analyzing large series of ${ }^{14} \mathrm{C}$ dates, centuries (from a single calibrated date) are turned into decades. Therefore, Bayesian analysis is even dubbed the "third radiocarbon revolution" (Current Archaeology 2007), while enabling more in-depth conclusions concerning the study of Neolithic long barrows (Bayliss et al. 2007).

It is this strategy of Bayesian analysis that was needed to address the intricate chronological problems involved in the Iron Age debate of the southern Levant. The key site in this respect is Tel Rehov. No other site in the region has such a dense stratigraphic database of 64 high-quality ${ }^{14} \mathrm{C}$ dates, mostly seeds, measured with systematic quality control analysis (van der Plicht and Bruins 2005). The series of Tel Rehov proved well suited for Bayesian analysis (Bruins et al. 2005a). The results clearly underline a High Chronology for the Iron Age in Israel and the southern Levant. Also, 

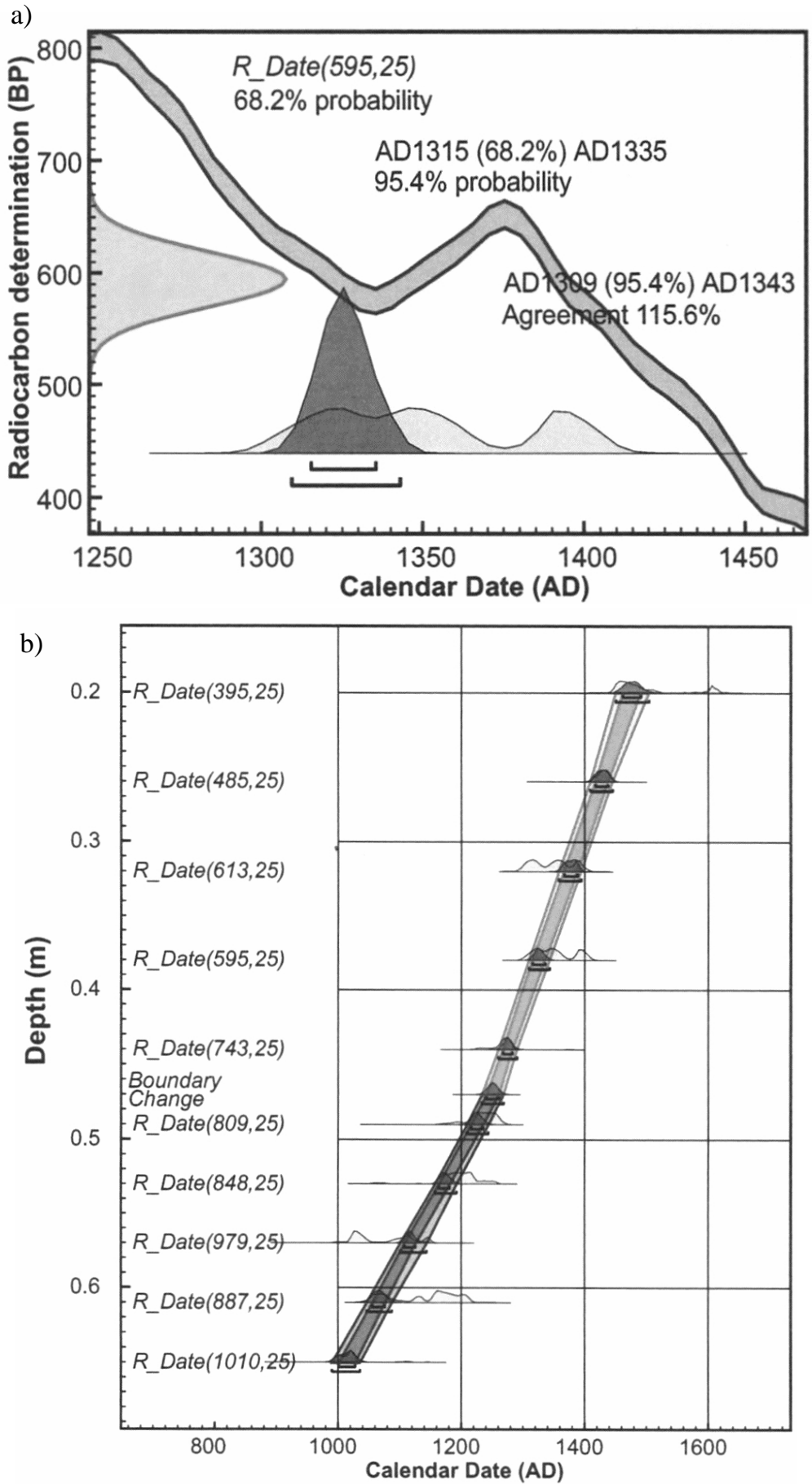

Figure 2 a) ${ }^{14} \mathrm{C}$ calibration probability distribution based on a single ${ }^{14} \mathrm{C}$ measurement (light gray), and based on analysis using an age model (dark gray); b) age-depth model with a series of ${ }^{14} \mathrm{C}$-dated samples. 
the 8 other sites from the Groningen database from the circum Mediterranean region support a High Chronology for the Iron Age in their respective regions, as presented in the following sections.

\section{THE SOUTHERN LEVANT}

\section{Tel Rehov}

Mazar (1999, 2003) conducted 6 excavation seasons at Tel Rehov during 1997-2003. The site is located in Israel at the strategic junction of the Jordan Valley and the Beth-Shean - Jizreel Valley. Tel Rehov exhibits a detailed stratigraphic sequence of the Iron Age, besides other periods; the large mound covers 10 hectares. Concerning literary sources, the name Rehov occurs at Karnak in Upper Egypt on the list of cities conquered by Pharaoh Shoshenq I, the biblical Shishak (I Kings 14:25-26, II Chronicles 12:3-4), and also appears in various Egyptian New Kingdom texts (Mazar et al. 2005). For a detailed description of the stratigraphy, archaeological context, pottery, and ${ }^{14} \mathrm{C}$ dates at $\mathrm{Tel}$ Rehov, see Mazar et al. (2005) and Bruins et al. (2007).

The Groningen date list includes 64 measurements from 21 different Iron Age loci at Tel Rehov. A number of large samples of charred cereal grains were suitable for high-precision dating. The conventional laboratory operates a set of 9 proportional gas counters, while 1 counter is especially suit-

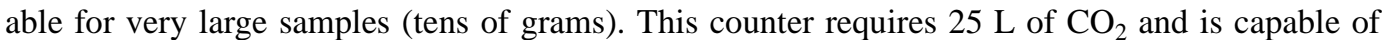
high-precision ${ }^{14} \mathrm{C}$ dating with standard errors $(1 \sigma)$ as low as $10-15 \mathrm{BP}$. Smaller gram-size samples were measured in other proportional counters, and intrinsically small samples (milligram-size) were measured by AMS. The list of all $64{ }^{14} \mathrm{C}$ dates is shown in stratigraphic order in Table 1 . Most Tel Rehov samples originate from a clear archaeological stratigraphic context, i.e. there is usually no association problem (Mazar et al. 2005). However, concerning 3 loci $(2618,6229,1224)$, there was a level of uncertainty whether the particular stratigraphic layer should be assigned to Stratum IV or V (Mazar et al. 2005), as indicated by a question mark in the date list. The majority of the samples consist of short-lived organic material: cereal grains and olive stones. Many samples were dated by multiple analyses. The duplicates overlap very well, mostly within $1 \sigma$, which justifies the calculation of weighted averages. This applies to both AMS (typical measurement errors 35-50 BP) and conventional results of large samples (mostly high precision; measurement errors around $15 \mathrm{BP}$ ).

The date list includes the measurements intended for additional testing of both the ${ }^{14} \mathrm{C}$ methodology and the archaeological chronological investigations. Baskets 54702 and 48115 constitute a "double duplication" test: charred seeds and olive pits were treated in duplicate (GrA-22301/22330 and GrA-22302/22329). These 4 samples were measured again by AMS at a later time (AMS measurement duplicate, same graphite targets). All measured ${ }^{14} \mathrm{C}$ dates underline the reliable reproducibility of the AMS system. Note that 1 set (basket 54702) had been dated earlier in triplicate as well (Table 1); all 7 measurements of this sample of cereal grains yielded similar ${ }^{14} \mathrm{C}$ dates within the standard error.

Homogeneity tests were performed for large samples of charred grains from baskets 24579 and 24647 , measured by the conventional laboratory. The sample material was divided into parts according to size fractions by sieving: coarse $(>850 \mu \mathrm{m})$, middle $(850-180 \mu \mathrm{m})$, and fine $(<180 \mu \mathrm{m})$. If the large sample would contain charred organic remains from different sources, this might show up in the ${ }^{14} \mathrm{C}$ results from the different size fractions. Concerning the sample from basket 24647, the fine fraction (GrN-27413) is significantly older $(2865 \pm 20 \mathrm{BP})$ than the coarse fraction $(2764 \pm 11$, GrN27364), well beyond their respective 2- $\sigma$ ranges. Therefore, it was suggested by Mazar et al. (2005) that the fine material is probably derived from charred wooden beams, occurring also in this destruction layer. 
However, the other samples that were split in terms of size fractions did not show an age difference. Concerning basket 24579, the 3 size fractions yielded similar ${ }^{14} \mathrm{C}$ dates. Concerning basket 24408b, also here the fine fraction $(\mathrm{GrN}-27412)$ and the coarse fraction $(\mathrm{GrN}-27362)$ of the same sample material gave identical ${ }^{14} \mathrm{C}$ dates, within the $1-\sigma$ error range.

Basket 44166 contained several organic materials: charred cereal grains, fine charcoal probably also derived from these grains, as well as a piece of animal bone. Collagen could be extracted from the bone material as the datable fraction (Mook and Streurman 1983). Though some differences exist between the various results from these organic materials, all ${ }^{14} \mathrm{C}$ dates are similar in physical terms, overlapping within the standard error of $2 \sigma$. Indeed, the important 5 dates from Stratum VI, the oldest Iron Age IIA layer, passed the chi-squared $\left(\chi^{2}\right)$ test performed by the OxCal program (Bronk Ramsey 1995) to evaluate statistically whether the 5 dates can be combined to calculate a weighted average. The results of the $\chi^{2}$ test gave $t=4.4$, which is well below the maximum allowed number of 9.5 in this case (Mazar et al. 2005:221).

Finally, a pretreatment test was performed. Seeds from basket 62430 were dated both in terms of the alkali fraction and the residue (the "normal" fraction). The chemical part of this experiment was done by the conventional laboratory. However, the separate alkali and residue fractions appeared too small for a precise conventional radiometric measurement. Hence, they were sampled and transferred to the AMS laboratory for further analysis. At the end, both fractions were put together again and measured by the conventional laboratory (total fraction, GrN-28368). The AMS measurements were done in duplicate to test reproducibility. The 5 resulting ${ }^{14} \mathrm{C}$ measurements are in good agreement in physical terms.

The stratified series of Iron Age ${ }^{14} \mathrm{C}$ dates from Tel Rehov, based on short-lived samples, form a well-suited case for Bayesian analysis. The result of our analysis is shown graphically in Figure 3. The computation results give an overall agreement well within 2- $\sigma$ confidence limits. The solid black fill in each calibration graph shows the same section selected by the Bayesian computation from within the full calibrated range. Thus, Bayesian statistics narrow down the width of the calibrated dates according to their stratigraphic time succession, thereby giving more precise results in historical years. This analysis of our stratified series of samples from Tel Rehov (Bruins et al. 2005) clearly supports a High Chronology, fitting with the revised traditional chronology of Mazar (2005), but being incompatible with the Low Chronology of Finkelstein $(1995,1996)$, see Table 1.

The youngest Iron Age IB layer at Tel Rehov (in area D) is Stratum D3, composed of refuse pits. The Bayesian statistical computation results for Locus 2862 (Figure 4) are shown here in more detail as an example. The $1-\sigma$ calibration range is $1009-971$ cal BCE, which means that somewhere within this time period appears the highest relative sample probability for the last stage of Iron IB, as represented at Tel Rehov.

The next youngest stratigraphic layer at Tel Rehov is Stratum VI (Iron IIA) in area C. The Bayesian model results are shown in Figure 5. The weighted average date for Stratum VI, $2772 \pm 11$ BP, intercepts the calibration curve at 2 places, reflected by the 2 peaks that reach a maximum relative probability level of 1 at the vertical axis. The Bayesian sampling computation according to the stratigraphic model selected the first peak as the most likely age range for Stratum VI, namely 971-958 cal BCE. This confirms the conclusions drawn by Bruins et al. (2003) in which Bayesian analysis had not yet been employed.

Placing the most probable results for Stratum D3 and Stratum VI in succession, it is clear that the boundary between Iron IB and Iron IIA may well be placed around $980 \mathrm{BCE}$, as suggested by Mazar 


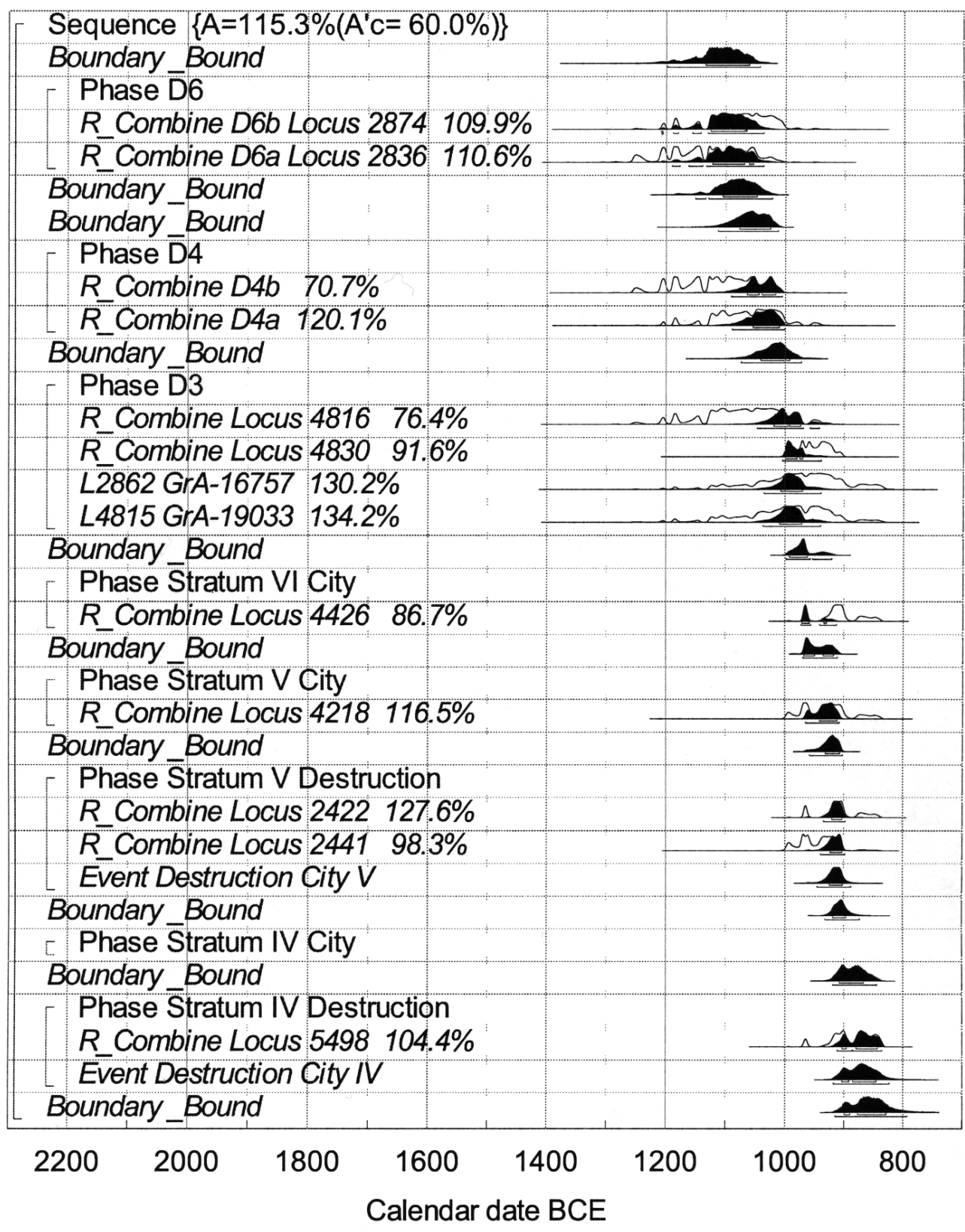

Figure 3 Bayesian statistical analysis results showing the calibrated age ranges, the sampled calibrated age ranges (solid black fill), as well as the sampled dates for boundaries and destruction events, according to the stratigraphy of Tel Rehov.

(2005). Placing this boundary around 900 or 920 BCE, as suggested by Finkelstein (2005), is very unlikely. Indeed, the sampled date for this boundary has the highest relative probability for the period 992-961 BCE ( $1 \sigma)$. The Bayesian results, given the stratigraphic model, thus contradict the Low Chronology suggestions by Finkelstein and Piasetzky (2003). 


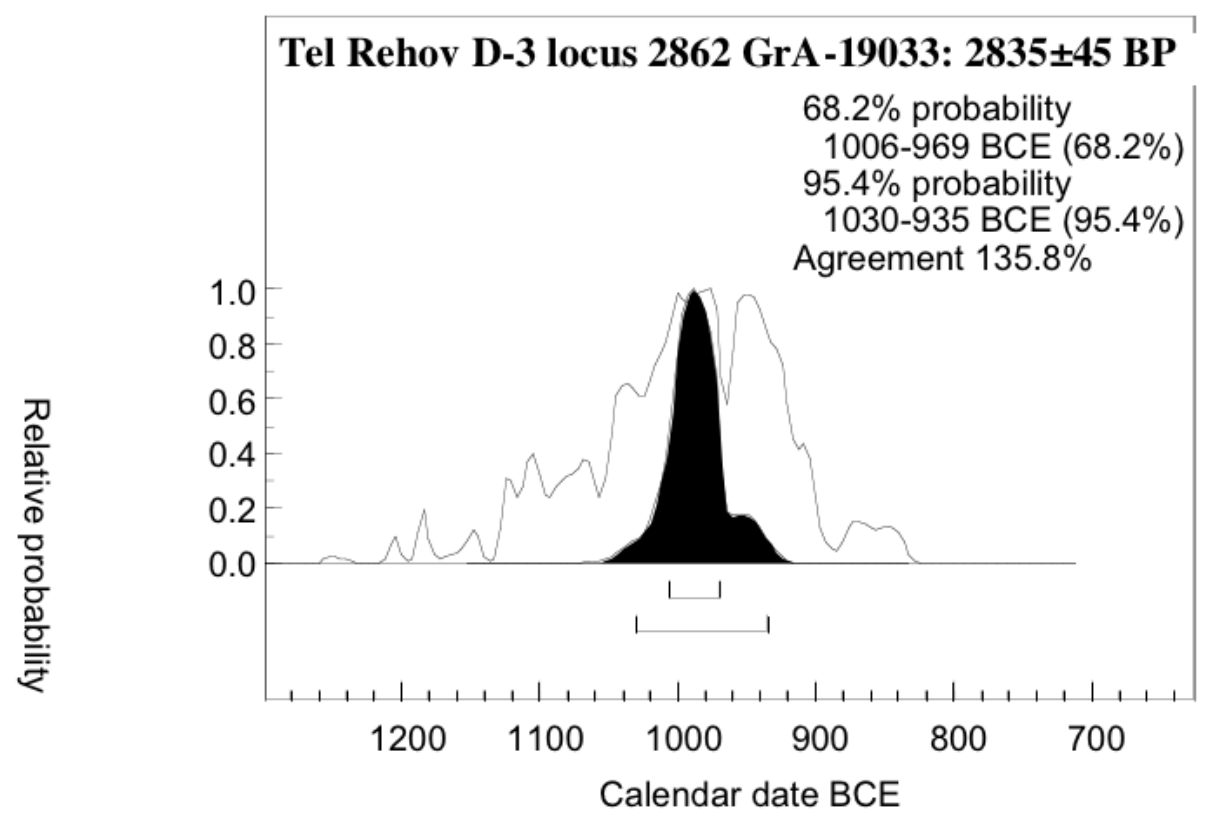

Figure 4 The Bayesian sampled date (solid black fill) from within the entire calibrated age range for Locus 2862 of Stratum D3, the youngest Iron Age IB layer at Tel Rehov.

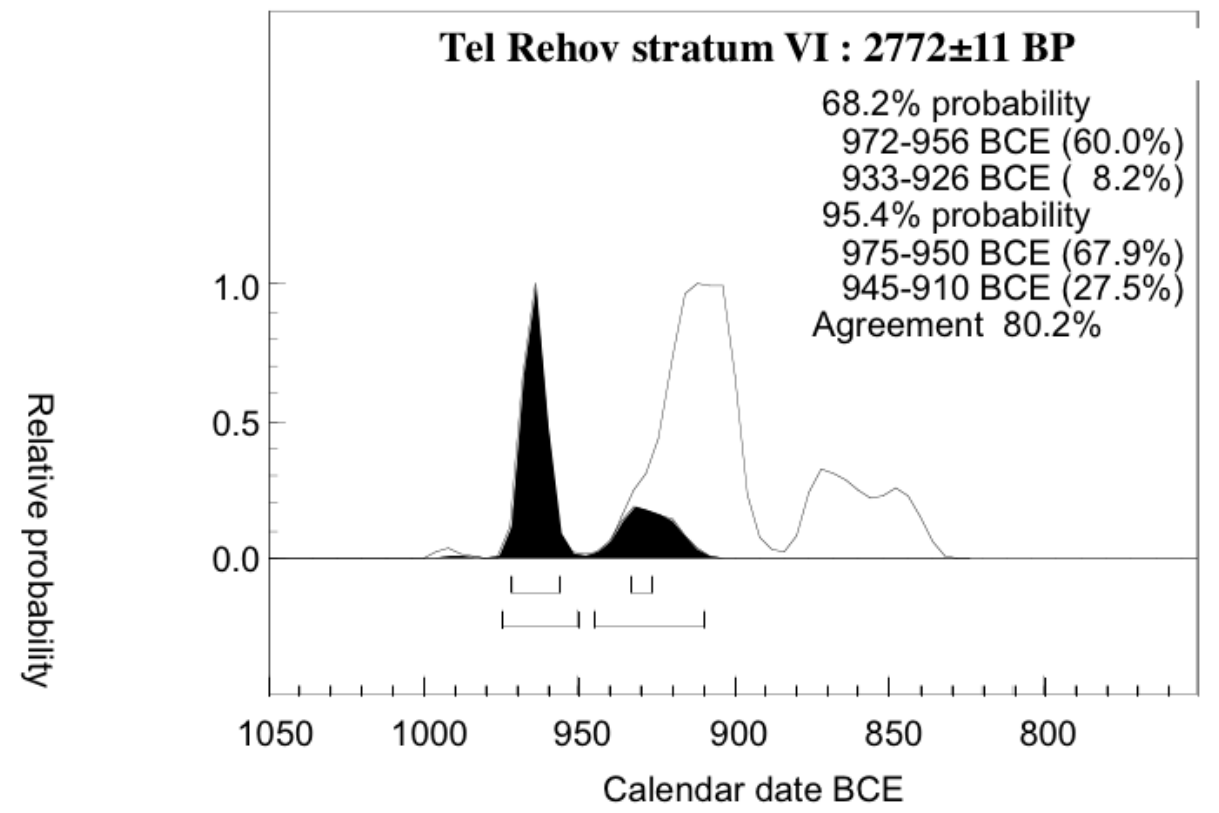

Figure 5 The Bayesian sampled date (solid black fill) from within the entire calibrated age range for Stratum VI, the oldest Iron Age IIA layer at Tel Rehov.

The Bayesian analysis (Figures 3-5) clearly illustrates the power of "archaeological wiggle matching," i.e. improving the temporal resolution of the calibrated dates, as indicated by the solid black filled curves. Most illustrative is the probability distribution shown in Figure 5. The full non-Baye- 
sian probability distribution (white, non-filled curve) yields 3 large peaks, of which the youngest two ( 910 and $\sim 860$ BCE) play a crucial role in the High/Low Chronology debate. These 2 peaks (almost) completely disappear in the Bayesian model (solid black curve in Figure 5).

The Bayesian analysis is discussed in full detail by Bruins et al. (2005a). In summary, the presented Bayesian stratigraphic model for Tel Rehov yields the following results (Bruins et al. 2005):

1. The Iron Age IB-IIA boundary falls in the 1- $\sigma$ range of $995-955$ BCE (66.4\%).

2. Stratum VI (early Iron IIA) has the most likely position in the range 972-956 BCE (60.0\%).

3. The City of Stratum V (Iron IIA) had a possible duration of 24-43 yr, in the 1- and 2- $\sigma$ ranges, respectively.

4. The destruction of City V occurred most likely in the full 1- $\sigma$ range of 924-904 BCE (68.2\%). This time range would fit possible association with the Asian campaign of Shoshenq I (Shishak), based on Egyptian criteria.

5. The City of Stratum IV (late Iron IIA) had a possible duration of $27-55 \mathrm{yr}$, in the 1- and 2- $\sigma$ ranges, respectively.

6. The destruction of City IV occurred most likely in the full 1- $\sigma$ range of 905-845 BCE (68.2\%).

Finally, the significance of ${ }^{14} \mathrm{C}$ dating as an intrinsically independent source of chronological information is underlined by its temporal classification of pottery. The Groningen ${ }^{14} \mathrm{C}$ dates from $\mathrm{Tel}$ Rehov show independently that ceramic assemblages defined as Iron Age IIA cover both the 10th and 9th centuries (Bruins et al. 2003; Mazar et al. 2005).

\section{Tel Dan}

Situated in the Rift Valley below Mount Hermon, the highest mountain in the entire region, Tel Dan lies in one of the best watered areas in Israel. The large mound covers 20 hectares. The Arabic name is Tell el-Qadi and its identification with biblical Dan is accepted; an inscription was found at the site, mentioning the name Dan (Biran 1993, 1994). The city of Dan appears repeatedly in the Bible, for example, as the northernmost part of Israel, but also by its older name Laish (Judges 18:29). It also appears as Laish in 2nd millennium BCE literary sources, such as the Egyptian Execretion Texts, in the Mari documents, and in the records of Thutmoses III (Biran 1994:21). The excavator of Tel Dan, Avraham Biran, conducted long-term excavations at Tel Dan in the period 1966-1993 (Biran 1994).

Bruins and van der Plicht selected organic samples from the Tel Dan collection in cooperation with Avraham Biran and David Ilan in order to investigate the ${ }^{14} \mathrm{C}$ chronology of the site. Unfortunately, short-lived charred seeds were rare and charcoal formed the dominant available sample material. A series of $20{ }^{14} \mathrm{C}$ dates were measured; the dates and associations are shown in Table 2. For a full discussion of our results, we refer to Bruins et al. (2005b). Two charred samples of olive stones, derived from Stratum V (Iron I) and IVA (Iron IIA), support the remarkably consistent charcoal dates, which are somewhat older because of the "old wood" effect (Bruins et al. 2005b). Another short-lived sample, consisting of charred seeds of Vicia faba and Pisum sativum, originally attributed to Stratum V, appeared to come from a Stratum III or II pit cut into Stratum V.

Our study underlines the importance of independent chronological ${ }^{14} \mathrm{C}$ studies; the original stratigraphic assignment was sometimes adjusted on the basis of the ${ }^{14} \mathrm{C}$ results. Most ${ }^{14} \mathrm{C}$ dates are from Stratum V, which archaeological age assessment placed at about 1150-1050 BCE (Biran 1994). The ${ }^{14} \mathrm{C}$ measurements of Stratum V (13th-11th century BCE on charred olive pits) confirm the above archaeological dating, but also allow for an even higher date. The ${ }^{14} \mathrm{C}$ results are undeniably older 
than the Low Chronology theory of Finkelstein (1999), who proposed a 10th century BCE date for Dan Stratum V. The ${ }^{14} \mathrm{C}$ date on charred olive pits from Stratum IVA yielded a calibrated age in the 11th-10th century BCE. Our set of ${ }^{14} \mathrm{C}$ dates from Tel Dan supports a High Chronology. However, more short-lived dates from new excavations are required to enlarge the database, refine the present results, and perhaps (depending on sample quality) allow for a full Bayesian analysis.

\section{Tell el-Qudeirat}

The site of Tell el-Qudeirat in the northeastern Sinai desert (Egypt) was excavated by Cohen (1981, 1993). The area, located near the copious spring of Ein el-Qudeirat, has been associated with biblical Kadesh-Barnea (Woolley and Lawrence 1914-1915). The excavations by Cohen uncovered 3 Iron Age fortresses at the tell, superimposed on each other. The Lower Fortress, the oldest of the 3, oval in shape, was archaeologically dated by Cohen to the 10th century BCE and associated with the time of King Solomon. However, a ${ }^{14} \mathrm{C}$ date from the lowermost destruction layer at the tell, belonging to the Lower Fortress, sampled by Bruins together with Cohen (Bruins and van der Plicht 2005, 2007), yielded a date of $2930 \pm 30 \mathrm{BP}(\mathrm{GrN}-12330)$. The calibrated date has a highest relative probability of 1195-1139 (32.1\%) within the 1- $\sigma$ range, using the OxCal program v 3.10 (Bronk Ramsey 1995, 2001) and the IntCal04 calibration curve (Reimer et al. 2004). This result is about $200 \mathrm{yr}$ older than the date suggested by Cohen $(1980,1981,1993)$. A destruction layer associated with the Middle Fortress also gave an older date than the archaeological age assessment (Bruins and van der Plicht 2005). The $2{ }^{14} \mathrm{C}$ dates for the destruction of the Upper Fortress fit with archaeological assessments and may be associated with the Babylonian military campaigns around $600 \mathrm{BCE}$ (Bruins and van der Plicht 2005). Therefore, ${ }^{14} \mathrm{C}$ dating at Tell el-Qudeirat is internally consistent (see Table 3), but gives a higher chronology for the older part of the Iron Age. Notice that concerning the Upper Fortress, the ${ }^{14} \mathrm{C}$ difference between the short-lived cereal grains and charred organic matter of unknown origin in the destruction layer is very small indeed. The "old wood" excuse cannot be used to dismiss the latter date, and likewise the other dates for the Middle and Upper Fortress should be taken seriously. The $4{ }^{14} \mathrm{C}$ dates related to the fortresses are presented in Table 3 .

\section{Horvat Haluqim}

Only $45 \mathrm{~km}$ northeast of Tell el-Qudeirat, as the crow flies, lies the site of Horvat Haluqim in the central Negev Desert (Israel). Horvat Haluqim consists of an ancient desert village, located along dry stream valleys (wadis) about $2 \mathrm{~km}$ northwest of Sede Boker (Figure 1). The site includes a comparatively large building, usually characterized as a kind of fortress, as well as houses and cisterns. A number of other structures were excavated by Cohen (1976), who assigned the oval-shaped fortress, similar in shape as the Lower Fortress at Tell el-Qudeirat, to the 10th century BCE, associated with the time of Solomon (Cohen 1980; Cohen and Cohen-Amin 2004). Geoarchaeological excavations in ancient agricultural wadi terraces at Horvat Haluqim were initiated by Bruins (1986) and are still continuing (Bruins and van der Plicht 2004, 2005, 2007). Excavations in terrace 12 of the eastern wadi revealed in the accumulative wadi sediments a detailed geoarchaeological stratigraphy, including living floors with archaeological objects. These finds will be published later. The ${ }^{14} \mathrm{C}$ dates of stratified organic material, including animal bones of sheep or goats, cover much of the Iron Age. The results show unambiguously that the site was occupied for a much longer period than merely the 10th century BCE. The 11th and 12th centuries BCE are present (like in Tell el-Qudeirat). The use of the terraced field includes the 13th-16th centuries BCE and extends even much further back in time (Bruins and van der Plicht 2005, 2007). These are the first stratified finds of the 2nd millennium $\mathrm{BCE}$ in the central Negev Desert. It is clear that ${ }^{14} \mathrm{C}$ dating gives a higher chronology than archaeological age assessments (Cohen 1976; Cohen and Cohen-Amin 2004), which limit settlement at Horvat Haluqim to only part of the 10th century BCE. A list of ${ }^{14} \mathrm{C}$ dates is presented in Table 4. 


\section{Khirbet en-Nahas}

Going from Horvat Haluqim east-southeast to the Arabah Valley, the distance to the ancient copper mining district of Faynan (biblical Edom) is $60 \mathrm{~km}$ as the crow flies. Here lies the site of Khirbat enNahas (Jordan), the largest Iron Age copper-smelting site in the southern Levant (Levy et al. 2004). The conventional archaeological view maintained that Iron Age settlement in the region, as well as the establishment of the Kingdom of Edom, occurred in the 8th-6th centuries BCE (Bennett 1977; Bienkowski 2001). The introduction of ${ }^{14} \mathrm{C}$ dating led to a different picture. Organic samples excavated at Khirbat en-Nahas (Levy et al. 2005) were dated in Groningen and Oxford (Higham et al. 2005). The list of the ${ }^{14} \mathrm{C}$ dates from Groningen is given in Table 5. The results show that Iron Age occupation at the site already existed in the early Iron Age (about 1200-1000 BCE), as well as in the 10th-9th centuries BCE. Therefore, 3 sites in the deserts of the southern Levant (Tell el-Qudeirat, Horvat Haluqim, and Khirbat en-Nahas) yielded ${ }^{14} \mathrm{C}$ dates that indicate human occupation in this region during the early Iron Age. These ${ }^{14} \mathrm{C}$ results present a higher chronology for the Iron Age, as compared to conventional archaeological age assessments.

\section{THE CENTRAL AND WESTERN MEDITERRANEAN}

As in Israel, a debate on the absolute chronology of the Iron Age rages in the western Mediterranean, mainly in Italy but also in other regions. Moreover, any reappraisal of the absolute chronology of the 10th and 9th centuries BCE in Israel touches upon synchronism and the historic role of the Phoenicians, since they were the main traders of Levantine goods that can be found all over the Mediterranean (Nijboer 2005; Nijboer and van der Plicht 2006, 2008). These Levantine imports/exports are the most important, archaeological carriers for synchronizing various cultures in the Mediterranean during the Iron Age.

In the past years, a research project on the Iron Age in the Mediterranean, primarily funded by the University of Groningen, concentrated on sound archaeological contexts from central Italy, mainly tombs. ${ }^{4}$ High-quality ${ }^{14} \mathrm{C}$ data associated with these contexts have resulted in chronological reference points for the period around $1000 \mathrm{BCE}$ and for the late 9th century BCE. It has also resulted in a reliable sequence of archaeological contexts with high-quality ${ }^{14} \mathrm{C}$ determinations, covering the Late Bronze Age and Iron Age in Latium Vetus (about 1200-800 BCE). Table 6 summarizes the results that give a clear decline in ${ }^{14} \mathrm{C}$ yr from 3000 to $2600 \mathrm{BP} .{ }^{5} \mathrm{In}^{14} \mathrm{C}$ yr, these results coincide with the data set published by the "Israel Project" that also gives a gradual decline in ${ }^{14} \mathrm{C}$ yr from about 3000 to 2600 BP (Sharon et al. 2007:24-44, Tables 7, 8). Both data sets are more or less synchronic and this does not create any dilemma because the archaeological contexts presented in Table 6 do not contain artifacts from the Levant. Nonetheless, Levantine artifacts can be traced in Italy from the 10th century BCE onwards (Nijboer, unpublished data).

Our Groningen Project was deemed necessary on account of the continued debate on absolute chronology since the late 1980s (Olde Dubbelink and van der Plicht 1990; Randsborg 1991; Nijboer et al. 1999/2000). Italian pre-historians started to raise the absolute chronology of the Iron Age in Italy on account of dendrochronological results from Switzerland and southern Germany, both regions

\footnotetext{
${ }^{4}$ The Groningen research on the "Absolute Chronology of the Iron Age in the Mediterranean" will be labeled in this paper "the Groningen Project."

${ }^{5}$ The date list represents only part of the ${ }^{14} \mathrm{C}$ dates obtained for Italy. The other ${ }^{14} \mathrm{C}$ results are not given since their archaeological contexts have not yet been published. In the Groningen Project a ${ }^{14} \mathrm{C}$ date without a published, archaeological context to which this date refers is considered to be of no value. One has to take our word that the unpublished ${ }^{14} \mathrm{C}$ dates for the Iron Age in Italy coincide more or less with those given in the date list.
} 
that maintained close cultural contacts with northern Italy during the Iron Age (Peroni 1994; Giardino 1995; Bietti Sestieri 1996). This dendrochronological research raised the absolute chronology for the Iron Age by almost a century and is in line with the ${ }^{14} \mathrm{C}$ results presented here. However, some of the ${ }^{14} \mathrm{C}$ results of the Groningen Project do not match the conventional absolute chronology that is based on a partial reading of Greek Geometric/Proto-Corinthian ceramics related to a text by Thucydides mentioning the Greek colonization of Sicily during the period 735-700 BCE (Nijboer 2005).

In this section of the paper, we will first present our ${ }^{14} \mathrm{C}$ results from Italy (Celano and Latium Vetus), after which we will introduce the evidence for the earliest Phoenician settlements in Spain and northern Africa.

\section{Latium Vetus}

A sound ${ }^{14} \mathrm{C}$ sequence was obtained for the region just south of Rome, known as Latium Vetus, covering the Late Bronze Age and the Iron Age in Italy (about $1200-800 \mathrm{BCE}$ ). The series of ${ }^{14} \mathrm{C}$ dates is presented in Table 6. The archaeological contexts are not discussed here, but can be found in the references as given by Nijboer and van der Plicht (2008) and Bietti Sestieri and De Santis (2008). It shows that the Late Bronze Age dates from 1200 to 950 BCE. Phases known as Latial I, II, and III date from 1050 to $950 \mathrm{BCE}$, from 950 to $825 / 800 \mathrm{BCE}$, and from 825/800 to $725 \mathrm{BCE}$, respectively.

Our measurements include samples from a well-preserved Iron Age hut at Fidene, Rome (Nijboer et al. 1999/2000). The ${ }^{14} \mathrm{C}$ dates indicate that the "conventional" chronology for the Iron Age in Italy should be raised by about 25 to $50 \mathrm{yr}$.

In order to test the conventional, absolute chronology for the western Mediterranean, ${ }^{14} \mathrm{C}$ samples were investigated from sites associated with the earliest evidence for Phoenicians: Huelva (Tartessos, southwest Spain; see Figure 1) and Carthage. Carthage was chosen because its foundation is historically known (814/813 BCE), and excavations reached the lowest levels of Carthage. In addition, recent research shows that the Phoenician advance to the far western Mediterranean must be dated to the 10th-9th century BCE, earlier than previously believed. The Phoenicians traded precious metals of western Mediterranean origin, including Tartessos.

Also from sites in central Italy, chronological reference points were obtained by series of ${ }^{14} \mathrm{C}$ measurements. We obtained samples from Celano and from the Latium Vetus region (see Figure 1 for the location of these sites).

\section{Celano}

At Celano in the Abruzzo region, some rare, Final Bronze Age tombs were excavated, yielding waterlogged, wooden sarcophagi with significant tree-ring sequences. Two of these tombs (tombs 4 and 5) are dated by wiggle-match dating (WMD). From each trunk, 5 tree-ring samples were large samples that could be dated by the conventional laboratory. The results are given in Table 7. Our analysis shows that the tumuli were erected around $1000 \pm 25 \mathrm{BCE}$, while the associated artifacts in the sarcophagi refer to the final stages of the Late Bronze Age in Italy.

The sarcophagi in both Celano tombs are made from oak (Quercus sp.) and no traces of bark or cambial rings were detected. So far, the presence of sapwood is not clear. The outermost rings of the tree trunk from Tomb 4 are of a different lighter color and tyloses are present in the vessels. The heartwood/sapwood transition zone is implied. ${ }^{6}$ Therefore, the absolute dates obtained for both tombs are a terminus post quem to which one needs to add a number of rings for the sapwood, 20-30 rings. Nonetheless, the premise is that little of the heartwood was removed while making the sarcophagus. 
Moreover, the WMD of both tombs coincide well with the ${ }^{14} \mathrm{C}$ sequence obtained for Latium Vetus (see Table 6).

Both tombs are assigned to the last stages of the Final Bronze Age in Italy on account of the associated fibulae (d'Ercole 1998). Related fibulae as the ones found in Tomb 4 and 5 at Celano have been recovered all over the Italian Peninsula and even in Croatia and nearby regions (cf. von Merhart and Kossack 1969: Tables 4, 5, and 7; Glogovic 2003).

Our date of $1000 \mathrm{BCE}$ for the last stages of the Final Bronze Age of Italy has consequences for the beginning of the Early Iron Age, which should start around 950 BCE, an assessment that is consistent with other ${ }^{14} \mathrm{C}$ sequences obtained for Italy, such as the sequence for Latium Vetus.

\section{Huelva}

At Huelva, there are 2 archaeological deposits, including artifacts with parallels in the Levant, and which are now ${ }^{14} \mathrm{C}$ dated (Nijboer and van der Plicht 2006). These 2 deposits are known as the Town and River deposits, respectively.

The Town deposits, found in a clear archaeological stratum, contained a wealth of material culture, including the oldest Phoenician material recovered thus far. Various cattle bones of substantial size (hundreds of grams) were found, which offered the opportunity for a precise ${ }^{14} \mathrm{C}$ date by the conventional method. Since there is material culture from the Levant, these dates have implications for the ongoing chronological discussions. Three conventional ${ }^{14} \mathrm{C}$ dates were obtained, which were identical within error (see Table 8). The averaged value for these 3 dates is $2755 \pm 15 \mathrm{BP}$, resulting in a calibrated age range of 920-845 BCE (1 $\sigma)$.

The River deposits yield a similar situation. Here, 6 samples of wood from throwing spears have been dated earlier in Spain (laboratory codes CSIC-202 through -207; Nijboer and van der Plicht 2008 and references therein). Also, these 6 dates are the same within error. Their average value is $2815 \pm 30$ BP, corresponding to the 10th century BCE. Both the Town and River deposits at Huelva contain material that can be found in Phoenicia as well, most significantly fibulae.

With these finds from Huelva, it becomes clear that the Phoenicians established trading links with the western Mediterranean prior to the Greeks. This significance of the ${ }^{14} \mathrm{C}$ dates lies as well in their relation with other ${ }^{14} \mathrm{C}$ dates for Phoenician settlements in the western Mediterranean.

It also bears on the "United Kingdom" discussion in Israel, which results from the High/Low Chronology discussion. According to the scriptures, King Hiram of Tyre and King Solomon built merchant fleets to collect precious metals from Tarshish, which is associated with Tartessos (Nijboer and van der Plicht 2006, 2008).

\section{Carthage}

Carthage in northern Africa (present-day Tunisia) can be considered the main western settlement of the Phoenicians. Its foundation is a very important anchor date for chronological studies. The most recent excavations (by the universities of Hamburg and Gent) date the Greek pottery from the oldest level to the second half of the 8th century. The ${ }^{14} \mathrm{C}$ dates from this level, however, are 50-75 yr older, consistent with the historical foundation of Carthage, which is 814/813 BCE.

${ }^{6}$ We would like to thank Drs N Martinelli and O Pignatelli of Dendrodata in Verona for this information. We intend to publish in the near future the dendrological information of both Celano tombs in detail. 
Samples from the oldest level were collected by the Hamburg team. Large quantities of cattle bone $(\sim 1 \mathrm{~kg})$ were dated conventionally. The results are shown in Table 9 . The 4 dates are the same within error; the averaged result is $2670 \pm 20 \mathrm{BP}$. Calibration of this averaged date yields $830-805 \mathrm{BCE}$ $(1 \sigma)$. This date for the earliest settlement layers is consistent with the traditional foundation date of Carthago (814/813 BCE) but not with the conventional chronology of the Greek ceramics present in the context (Nijboer and van der Plicht 2006).

Thus, these ${ }^{14} \mathrm{C}$ dates from Carthage also show that Phoenicians were present in Carthago during the late 9th century BCE, especially if one takes into account that the area investigated is not considered to be the oldest part of the settlement.

Recently, the Carthage excavations were continued by the Gent team. This excavation produced 13 ${ }^{14} \mathrm{C}$ dates (including 3 duplicate measurements). These results are also shown in Table 9. This set of ${ }^{14} \mathrm{C}$ dates is slightly younger than the Hamburg material. Unfortunately, from the viewpoint of precise dating, that moves them into the Hallsttatt plateau of the calibration curve. Even so, they still refer to the period around $800 \mathrm{BCE}$ (Docter et al., in press).

\section{DISCUSSION}

The ${ }^{14} \mathrm{C}$ dates from the western Mediterranean substantiate a late 9th century BCE date for the foundation of Phoenician Carthage. The Huelva (Tartessos) and Carthage ${ }^{14} \mathrm{C}$ dates are a clear indication that Phoenician contacts with cultures in the western Mediterranean are older than previously thought. They start probably during the first half of the 9th century BCE, if not before (Nijboer 2005; Nijboer and van der Plicht 2006).

The mean age of the Huelva ${ }^{14} \mathrm{C}$ dates $(2755 \pm 15 \mathrm{BP})$ coincides with the weighted average date obtained for Tel Rehov (Israel) Stratum IV (2755 \pm 25 BP) (Bruins et al. 2003; Mazar et al. 2005). This observation implies a synchronism on the basis of ${ }^{14} \mathrm{C}$ dating, which enables correlation on the basis of time, even in the absence of cultural-material links.

Concerning the southern Levant, Finkelstein and Piasetzky (2006) attempted to place our dating results into the Low Chronology perspective. They removed 4 of the 5 dates from Stratum VI and retained only 1 comparatively young date obtained on cereal grains. However, all 5 dates are acceptable in terms of the $\chi^{2}$ test, as explained above. Moreover, a bone also classifies as short-lived material, while the 3 AMS measurements of the fine charcoal have both younger and older results in comparison to the conventional date of the grains. Fine charcoal is not necessarily originating from old wood. The weighted average date of the 5 samples is $2772 \pm 11 \mathrm{BP}$, which is the same (within $1 \sigma)$ as the single date of the cereal grains $(2761 \pm 14, \mathrm{GrN}-27366)$. However, the main methodological shortcoming of Finkelstein and Piasetzky (2006) is their disregard for Bayesian sequence analysis (Bruins et al. 2005a). It is precisely this Bayesian analysis that enabled our enhanced chronological conclusions concerning Tel Rehov. We made test runs of alternative Bayesian model options, but all gave similar results, placing Stratum VI in the oldest half of the 10th century BCE: "Stratum VI has its most likely 1- $\sigma$ position in the range $971-958$ BCE (62.4\%). The 3 model options that were tested, with or without R_Combine, all selected more or less the above time period" (Bruins et al. 2005a:292).

Concerning the beginning of Stratum VI, the boundary between Iron Age IB and Iron Age IIA in the $1-\sigma$ range is $992-961$ BCE (68.2\%) according to Bayesian analysis. This result fits very well indeed with the suggestion of Mazar (2005) on archaeological and textual grounds to place this boundary around 980 BCE. 
The Bayesian analysis for the destruction of Rehov City (Stratum) V, which was proposed to possibly relate to the Asian campaign by Pharaoh Shoshenq I (Bruins et al. 2003), resulted in a date of 924902 BCE $(1 \sigma)$ and $945-887$ BCE $(2 \sigma)$. Rehov is mentioned in the list of places raided by Pharaoh Shoshenq I, as recorded in stone at Karnak in Egypt on the southern wall of the Amun temple. The Asian campaign of Shoshenq I (the biblical Shishak of I Kings 11 and 14, as well as II Chronicles 12), has been put at 925 BCE by Kitchen (2000), based on both Egyptian and biblical chronological data. However, a date around 920 BCE would also be feasible, based on Egyptian texts only, according to Shortland (2005). Therefore, a temporal coincidence exists between the ${ }^{14} \mathrm{C}$ dates for the destruction of Rehov Stratum V and the estimated historical date for the campaign of Shoshenq I.

The ${ }^{14} \mathrm{C}$ date list of Tel Rehov and the Bayesian sequence analysis does not support the Low Chronology point of view (Finkelstein 1996, 2005; Finkelstein and Piasetzky 2003, 2006; Gilboa and Sharon 2001, 2003; Boaretto et al. 2005; Sharon et al. 2007), in which the boundary between Iron Age I and Iron Age II is usually placed around 900 or 920 BCE.

Boaretto et al. (2005) consider their dates related to the Iron Age I/II transition as inconsistent with our Tel Rehov results, measured in Groningen. They favor a younger date for this transition (in the range 910-875 BCE). What is lacking in their approach is an individual stratigraphic presentation and analysis of the Iron Age I/II transition for each individual archaeological site. Putting all the dates of many sites together in one mix does not seem helpful. It increases complexity in a nontransparent manner and it prevents systematic evaluation of both individual and successive strata for each site in archaeological and ${ }^{14} \mathrm{C}$ terms. Boaretto et al. (2005) conclude, based on an intercomparison between the ${ }^{14} \mathrm{C}$ laboratories of Rehovot and Tucson (but also including some Groningen dates), that there is general good agreement between the laboratories. This observation is in itself correct, and is based on comparing ${ }^{14} \mathrm{C}$ dates with $1-\sigma$ errors ranging between 20 and $60 \mathrm{BP}$. But these are single dates. Taken together with the fluctuations in the calibration curve for the time range considered, single dates usually cannot distinguish between the High or Low Chronology propositions without Bayesian modeling. This is the main problem also with the approach taken by Finkelstein and Piasetzky $(2003,2006)$.

A comprehensive report of the "Israel Project," based on extensive analysis of Iron Age ${ }^{14} \mathrm{C}$ dates of 21 sites, was published recently by Sharon et al. (2007). The statistical group analysis of the results is claimed by the authors to support a Low Chronology for the Iron Age in the Levant. This report follows previous publications concerning various stages of their research (Gilboa and Sharon 2001, 2003; Boaretto et al. 2005), in which the Low Chronology is systematically favored, following Finkelstein $(1995,1996,1999,2005)$. In terms of ${ }^{14} \mathrm{C}$ dating, several of these publications are difficult to evaluate, as lists of ${ }^{14} \mathrm{C}$ dates (before calibration), the presumed basis for the authors' conclusions, were not provided. However, the latest publication (Sharon et al. 2007: Table 7) does give a valuable list of all individual dates, though the $\delta^{13} \mathrm{C}$ values of the dates, important for quality control evaluation, are not included.

One of us evaluated the Israel Iron Age Project (Sharon et al. 2007) in both archaeological and ${ }^{14} \mathrm{C}$ terms, in a manuscript entitled "Concepts of time, synchronism and the Iron Age in the Mediterranean" (Nijboer, submitted). Indeed, we object to the group treatment approach by Sharon et al. (2007), in the way they combine $61{ }^{14} \mathrm{C}$ dates from 18 archaeological contexts related to the Iron Age IIA. These $61{ }^{14} \mathrm{C}$ dates show a large range of variation from 2900 to $2450 \pm 50 \mathrm{BP}$ (Sharon et al. 2007:35-38, Table 7). Their approach to calculate overall mean values of all sites combined with the exclusion of outliers and misfits seems rather pointless for determining the absolute date for the emergence of the Iron Age IIA in ancient Israel. 
Sharon et al. (2007) merge ${ }^{14} \mathrm{C}$ dates from 21 sites and several contexts without discussing in detail the quality of each ${ }^{14} \mathrm{C}$ result nor the temporal resolution of the individual contexts dated. We suggest that a combined date of $900 \pm 25 \mathrm{BCE}$ as obtained by Sharon et al. (2007) may reflect the average age of Iron IIA contexts but does not necessarily date the beginning or end of this phase. About $30 \%$ of the contexts (Sharon et al. 2007: Table 7) have a difference over $100 \mathrm{BP}$ in the ${ }^{14} \mathrm{C}$ ages. Such discrepancies are too large in terms of the International Radiocarbon Intercomparisons (Scott 2003), making conclusions concerning temporal resolutions within a century (as is required for any conclusion concerning "high" versus "low") not justified.

\section{CONCLUSIONS}

This special issue of the journal Radiocarbon is dedicated to its 50th anniversary. After more than 50 years, ${ }^{14} \mathrm{C}$ dating has reached the proverbial age to see Abraham, and the method can now go back to where it started: the Near East. Libby used historical Egyptian material to test his ${ }^{14} \mathrm{C}$ dating invention. By now, the ${ }^{14} \mathrm{C}$ method has reached the reversed situation, as historical and proto-historical chronological uncertainties in the Near East and around the Mediterranean are now increasingly being investigated with ${ }^{14} \mathrm{C}$ dating.

Though the Low Chronology for the Iron Age in the southern Levant has become quite fashionable, we disagree on scientific and archaeological grounds, as presented above. To squeeze out 60-100 yr from the flow of time in the past, in order to lower the boundary between Iron Age I and Iron Age II in the southern Levant from roughly 1000/980 to about $920 / 900$, is not easy. The Groningen ${ }^{14} \mathrm{C}$ database, as presented in this article, does not support a Low Chronology for any of the 9 sites in the southern Levant and circum Mediterranean region.

Bayesian statistical analysis, the latest revolution in ${ }^{14} \mathrm{C}$ dating, showed that for Tel Rehov-the Iron Age site with the largest number of ${ }^{14} \mathrm{C}$ dates, the most detailed stratigraphic resolution, and the largest number of samples based on short-lived seeds-the Iron I/II boundary is situated in the 1- $\sigma$ range of 992-961 BCE.

The Groningen ${ }^{14} \mathrm{C}$ results, involving both AMS and proportional gas counter dates, give evidence, without exception, of a high Iron Age chronology for all sites presented: Tel Rehov, Tel Dan, Tell elQudeirat, Horvat Haluqim, Khirbet en-Nahas, Celano, Latium Vetus, Carthage, and Huelva. There are no group treatment manipulations that obscure the context of each individual site, stratum, and date. Every site is evaluated on an individual stratigraphic basis, giving joint information concerning the archaeological context and each ${ }^{14} \mathrm{C}$ date. This is in our opinion the correct approach to move forward.

\section{REFERENCES}

Balter M. 2000. The two tels: Armageddon for biblical archaeology? Science 287(5450):31-2.

Bayliss A, Bronk Ramsey C, van der Plicht J, Whittle A. 2007. Bradshaw and Bayes: towards a timetable for the Neolithic. Cambridge Archaeological Journal 17(S1):1-28.

Bennett C-M. 1977. Excavations in Buseirah, southern Jordan, 1974. Fourth preliminary report. Levant 9:110.

Berger R. 1983. Willard Frank Libby, 1908-1980. In: Mook WG, Waterbolk HT, editors. Proceedings of the Groningen Symposium on ${ }^{14} \mathrm{C}$ and Archaeology. PACT 8:13-6.
Bienkowski P. 2001. Iron Age settlement in Edom: a revised framework. In: Daviau PMM, Wevers JW, Weigl M, editors. The World of the Aramaeans. II. Studies in History and Archaeology in Honour of Paul-Eugen Dion. Sheffield: Sheffield Academic Press. p 257-69.

Bietti Sestieri AM. 1996. Protostoria, Teoria e Pratica. Rome: La Nuova Italia Scientifica. 372 p. In Italian.

Bietti Sestieri AM, De Santis A. 2008. Relative and absolute chronology of Latium Vetus from the Bronze Age to the transition to the Orientalizing period. In: Brandherm D, Trachsel M, editors. A New Dawn for the Dark Age? Shifting Paradigms in Mediterranean Iron Age Chronology. Proceedings of the XV UISPP 
World Congress (Lisbon, 4-9 September 2006). BAR S1871. Oxford: Archaeopress.

Biran A. 1993. Dan. In: Stern E, editor. The New Encyclopaedia of Archaeological Excavations in the Holy Land, I. New York: Simon and Schuster. p 323-32.

Biran A. 1994. Biblical Dan. Jerusalem: Hebrew Union College. 280 p.

Boaretto E, Jull AJT, Gilboa A, Sharon I. 2005. Dating the Iron Age I/II transition in Israel: first intercomparison results. Radiocarbon 47(1):39-55.

Bronk Ramsey C. 1995. Radiocarbon calibration and analysis of stratigraphy: the OxCal program. Radiocarbon 37(2):425-30.

Bronk Ramsey C. 2001. Development of the radiocarbon calibration program. Radiocarbon 43(2A):355-63.

Bronk Ramsey C. 2008. Deposition models for chronological records. Quaternary Science Reviews 27(1-2): $42-60$.

Bronk Ramsey C, Buck CE, Manning SW, Reimer P, van der Plicht J. 2006. Developments in radiocarbon calibration for archaeology. Antiquity 80(310):783-98.

Bruins HJ. 1986. Desert environment and agriculture in the central Negev and Kadesh-Barnea during historical times [PhD dissertation]. Wageningen University. Published by Stichting Midbar Foundation, Nijkerk.

Bruins HJ, van der Plicht J. 2004. Desert settlement in the central Negev: first ${ }^{14} \mathrm{C}$ indication of rainwater-harvesting agriculture in the Iron Age. In: Higham TFG, Bronk Ramsey C, Owen DC, editors. Radiocarbon and Archaeology: Proceedings of the 4th International Symposium. Oxford, 2002. Oxford: Oxford University, School of Archaeology, Monograph 62. p 83-98.

Bruins HJ, van der Plicht J. 2005. Desert settlement through the Iron Age: radiocarbon dates from Sinai and the Negev highlands. In: Levy TE, Higham T, editors. The Bible and Radiocarbon Dating: Archaeology, Text and Science. London: Equinox. p 349-66.

Bruins HJ, van der Plicht J. 2007. Radiocarbon dating the "Wilderness of Zin." Radiocarbon 49(2):481-97.

Bruins H, Carmi I, Boaretto E, editors. 2001. Near East Chronology: Archaeology and Environment (special issue). Radiocarbon 43(3):1147-390.

Bruins HJ, van der Plicht J, Mazar A. $2003 .{ }^{14} \mathrm{C}$ dates from Tel Rehov: Iron-Age chronology, pharaohs and Hebrew kings. Science 3000(5617):315-8.

Bruins HJ, van der Plicht J, Mazar A, Bronk Ramsey C, Manning SW. 2005a. The Groningen radiocarbon series from Tel Rehov: OxCal Bayesian computations for the Iron IB-IIA boundary and Iron IIA destruction events. In: Levy TE, Higham T, editors. The Bible and Radiocarbon Dating: Archaeology, Text and Science. London: Equinox. p 271-93.

Bruins HJ, van der Plicht J, Werker E, Ilan D. 2005b. Iron Age ${ }^{14} \mathrm{C}$ dates from Tel Dan: a High Chronology. In: Levy TE, Higham T, editors. The Bible and Radiocarbon Dating: Archaeology, Text and Science. London: Equinox. p 323-36.
Bruins HJ, Mazar A, van der Plicht J. 2007. The end of the 2nd millennium BCE and the transition from Iron I to Iron IIA: radiocarbon dates from Tel Rehov, Israel. In: Bietak M, Czerny E, editors. Proceedings of the 2nd SCIEM Euroconference. Vienna: Austrian Academy of Sciences. p 79-99.

Cohen R. 1976. Excavations at Horvat Haluqim. Atiqot 11:34-50.

Cohen R. 1980. The Iron Age fortresses in the central Negev. Bulletin of the American Schools of Oriental Research 236:61-79.

Cohen R. 1981. Excavations at Kadesh-barnea 19761978. Biblical Archaeologist 44(2):93-107.

Cohen R. 1993. Kadesh-Barnea. The Israelite fortress. In: Avi-Yonah M, editor. The New Encyclopedia of Archaeological Excavations in the Holy Land. Volume 3. New York: Simon and Schuster. p 843-7.

Cohen R, Cohen-Amin R. 2004. Ancient Settlement of the Central Negev. Volume II. The Iron Age and the Persian Period. Jerusalem: The Israel Antiquities Authority, IAA Reports No. 20. In Hebrew with English summary.

Current Archaeology. 2007. The New Radiocarbon Dating Revolution (special issue). Current Archaeology 209:9-20.

d'Ercole V. 1998. La necropoli dell'età del Bronzo Finale delle "Paludi" di Celano. In: D'Ercole V, Cairoli R, editors. Archeologia in Abruzzo. Montalto di Castro: Tarquinia. p 157-66. In Italian.

de Jong AFM, Mook WG, Becker B. 1989. Corrected calibration of the radiocarbon time scale, 3904-3203 cal BC. Radiocarbon 31(2):201-10.

Docter RF, Chelbi F, Telmini BM, Nijboer AJ, van der Plicht J, van Neer W, Mansel K, Garsallah S. In press. New radiocarbon dates from Carthage: bridging the gap between history and archaeology? In: Sagona C, editor. Beyond the Homeland: Markers in Phoenician Chronology. Ancient Near Eastern Studies Supplement Series 28. Leuven: Peeters Press.

Finkelstein I. 1995. The date of the settlement of the Philistines in Canaan. Tel Aviv 22:213-39.

Finkelstein I. 1996. The archaeology of the United Monarchy: an alternative view. Levant 28:177-87.

Finkelstein I. 1999. Hazor and the North in the Iron Age: a Low Chronology perspective. Bulletin of the American Schools of Oriental Research 314:55-70.

Finkelstein I. 2005. A Low Chronology update: archaeology, history and the Bible. In: Levy TE, Higham T, editors. The Bible and Radiocarbon Dating: Archaeology, Text and Science. London: Equinox. p 31-42.

Finkelstein I, Piasetzky E. 2003. Comment on " ${ }^{14} \mathrm{C}$ dates from Tel Rehov: Iron-Age chronology, pharaohs, and Hebrew kings." Science 302(5645):568.

Finkelstein I, Piasetzky E. 2006. The Iron I-IIA in the Highlands and beyond: ${ }^{14} \mathrm{C}$ anchors, pottery phases and the Shosenq I campaign. Levant 38:45-61.

Giardino C. 1995. Il Mediterraneo Occidentale fra XIV 
ed VIII secolo a.C.; Cerchie minerarie e metallurgia [The West Mediterranean between the 14th and 8th Centuries BC: Mining and Metallurgical Spheres]. BAR S612. Oxford: Archaeopress. In Italian.

Gilboa A, Sharon I. 2001. Early Iron Age radiometric dates from Tel Dor: preliminary implications for Phoenicia and beyond. Radiocarbon 43(2A):1343-52.

Gilboa A, Sharon I. 2003. An archaeological contribution to the Early Iron Age chronological debate: alternative chronologies for Phoenicia and their effects on the Levant, Cyprus and Greece. Bulletin of the American Schools of Oriental Research 332:7-80.

Glogovic G. 2003. Fibeln im Kroatischen Küstengebied (Istrien, Dalmatien). PBF, Abt. XIV, Band 13. Stuttgart. 90 p. In German.

Higham T, van der Plicht J, Bronk Ramsey C, Bruins HJ, Robinson M, Levy TE. 2005. Radiocarbon dating of the Khirbat-en Nahas site (Jordan) and Bayesian modeling of the results. In: Levy TE, Higham T, editors. The Bible and Radiocarbon Dating: Archaeology, Text and Science. London: Equinox. p 164-78.

Jamieson-Drake DW. 1991. Scribes and Schools in Monarchic Judah. Journal for the Study of the Old Testament. Supplement Series 109. Sheffield: Sheffield University Press. 240 p.

Kenyon KM. 1960. Archaeology in the Holy Land. London: Ernest Benn, Ltd. 326 p.

Kitchen KA. 2000. The historical chronology of ancient Egypt, a current assessment. In: Bietak M, editor. The Synchronization of Civilizations in the Eastern Mediterranean in the Second Millennium B.C. Vienna: Österreichische Akademie der Wissenschaften. p 39-52.

Levy TE, Adams RB, Najjar M, Hauptmann A, Anderson JA, Brandl B, Robinson MA, Higham T. 2004. Reassessing the chronology of biblical Edom: new excavations and ${ }^{14} \mathrm{C}$ dates from Khirbat en-Nahas (Jordan). Antiquity 78(302):865-79.

Levy TE, Najjar M, van der Plicht J, Higham T, Bruins HJ. 2005. Lowland Edom and the High and Low chronologies: Edomite state formation, the Bible and recent archaeological research in southern Jordan. In: Levy TE, Higham T, editors. The Bible and Radiocarbon Dating: Archaeology, Text and Science. London: Equinox. p 129-63.

Libby WF. 1952. Radiocarbon Dating. Chicago: University of Chicago Press. 124 p.

Mazar A. 1999. The 1997-1998 excavations at Tel Rehov: preliminary report. Israel Exploration Journal 49:1-42.

Mazar A. 2003. The excavations at Tel Rehov and their significance for the study of the Iron Age in Israel. Eretz Israel 27:143-60.

Mazar A. 2005. The debate over the chronology of the Iron Age in the southern Levant: its history, the current situation, and a suggested resolution. In: Levy TE, Higham T, editors. The Bible and Radiocarbon Dating: Archaeology, Text and Science. London: Equinox. p 15-30.
Mazar A, Bruins HJ, Panitz-Cohen N, van der Plicht J. 2005. Ladder of time at Tel Rehov: stratigraphy, archaeological context, pottery and radiocarbon dates. In: Levy TE, Higham T, editors. The Bible and Radiocarbon Dating: Archaeology, Text and Science. London: Equinox. p 193-255.

Mook WG. 1986. Business meeting: recommendations/ resolutions adopted by the Twelfth International Radiocarbon Conference. Radiocarbon 28(2A):799.

Mook WG, Streurman HJ. 1983. Physical and chemical aspects of radiocarbon dating. In: Mook WG, Waterbolk HT, editors. Proceedings of the Groningen Symposium on ${ }^{14} \mathrm{C}$ and Archaeology. PACT 8:31-55.

Mook WG, van der Plicht J. 1999. Reporting ${ }^{14} \mathrm{C}$ activities and concentrations. Radiocarbon 41(3):227-39.

Mook WG, Waterbolk HT. 1985. Handbook for Archaeologists no. 3, Radiocarbon Dating. Strasbourg: European Science Foundation. 65 p.

Nijboer AJ. 2005. The Iron Age in the Mediterranean: a chronological mess or trade before the flag. Ancient West and East 4:255-77.

Nijboer AJ, van der Plicht J. 2006. An interpretation of the radiocarbon determinations of the oldest indigenous Phoenician stratum thus far, excavated at Huelva, Tartessos (south-west Spain). Babesch 81: 31-6.

Nijboer AJ, van der Plicht J. 2008. The Iron Age in the Mediterranean: recent radiocarbon research at the University of Groningen. In: Brandherm D, Trachsel M, editors. A New Dawn for the Dark Age? Shifting Paradigms in Mediterranean Iron Age Chronology. Proceedings of the XV UISPP World Congress (Lisbon, 4-9 September 2006). BAR S1871. Oxford: Archaeopress.

Nijboer AJ, van der Plicht J, Bietti Sestieri AM, De Santis A. 1999/2000. A high chronology for the early Iron Age in central Italy. Palaeohistoria 41/42:163-76.

Olde Dubbelink RA, van der Plicht J. 1990. Le Capanne II e IV a Borgo le Ferriere (Satricum) e le datazione al radiocarbonico. Archeologoa Laziale X. Quaderni di Archeologia Etrusco-Italica 19:234-7. In Italian.

Pearson GW, Stuiver M. 1986. High-precision calibration of the radiocarbon time scale, 500-2500 BC. $R a$ diocarbon 28(2B):839-62.

Peroni R. 1994. Introduzione alla Protostoria Italiana. Rome: Laterza. 342 p. In Italian.

Randsborg K. 1991. Historical implications, chronological studies in European archaeology c. 2000-500 BC. Acta Archeologica 62:89-109.

Renfrew C. 1999. Before Civilization: The Radiocarbon Revolution and Prehistoric Europe. New edition. London: Pimlico. 320 p.

Reimer PJ, Baillie MGL, Bard E, Bayliss A, Beck JW, Bertrand CJH, Blackwell PG, Buck CE, Burr GS, Cutler KB, Damon PE, Edwards RL, Fairbanks RG, Friedrich M, Guilderson TP, Hogg AG, Hughen KA, Kromer B, McCormac G, Manning S, Bronk Ramsey C, Reimer RW, Remmele S, Southon JR, Stuiver M, 
Talamo S, Taylor FW, van der Plicht J, Weyhenmeyer CE. 2004. IntCal04 terrestrial radiocarbon age calibration, 0-26 cal kyr BP. Radiocarbon 46(3):1029-58.

Scott EM, editor. 2003. The 3rd International Radiocarbon Intercomparison (TIRI) and the 4th International Radiocarbon Intercomparison (FIRI). Radiocarbon 45(2):135-408.

Sharon I, Gilboa A, Jull AJT, Boaretto E. 2007. Report on the first stage of the Iron Age Dating Project in Israel: supporting a Low Chronology. Radiocarbon 49(1):146.

Shortland AJ. 2005. Shishak, King of Egypt: the challenges of Egyptian calendrical chronology. In: Levy TE, Higham T, editors. The Bible and Radiocarbon Dating: Archaeology, Text and Science. London: Equinox. p 43-54.

Stuiver M, Pearson GW. 1986. High-precision calibration of the radiocarbon time scale, AD 1950-500 BC. Radiocarbon 28(2B):805-38.

Tuniz C, Bird JR, Fink D, Herzog GF. 1998. Accelerator Mass Spectrometry: Ultrasensitive Analysis for Global Science. Boca Raton, Florida, USA: CRC Press. $371 \mathrm{p}$.

van der Plicht J, Bruins HJ. 2001. Radiocarbon dating in Near-Eastern contexts: confusion and quality control.
Radiocarbon 43(3):1155-66.

van der Plicht J, Bruins HJ. 2005. Quality control of Groningen ${ }^{14} \mathrm{C}$ results from Tel Rehov: repeatability and intercomparison of proportional gas counting and AMS. In: Levy TE, Higham T, editors. The Bible and Radiocarbon Dating: Archaeology, Text and Science. London: Equinox. p 256-70.

Van Strydonck M, Nelson DE, Crombé P, Bronk Ramsey C, Scott EM, van der Plicht J, Hedges REM. 1999. What's in a ${ }^{14} \mathrm{C}$ date. In: Évin J, Oberlin C, Daugas JP, Salles J-F, editors. ${ }^{14} \mathrm{C}$ et Archéologie $\left({ }^{14} \mathrm{C}\right.$ and $\mathrm{Ar}-$ chaeology). Rennes: Université de Rennes. p 433-40. von Merhart G, Kossack G. 1969. Hallstatt und Italien: gesammelte Aufsätze zur Frühen Eisenzeit in Italien und Mitteleuropa. Mainz: Verlag des Römisch-Germanischen Zentralmuseums. In German. 464 p.

Weinstein JM. 1984. Radiocarbon dating in the southern Levant. Radiocarbon 26(3):297-366.

Wightman GJ. 1990. The myth of Solomon. Bulletin of the American Schools of Oriental Research 277/278: 5-22.

Woolley CL, Lawrence TE. 1914-1915. The Wilderness of Zin. Palestine Exploration Fund, Annual. London: Harrison and Sons. Reprinted 2003. London: Palestine Exploration Fund and Stacey International.

\section{THE GRONINGEN RADIOCARBON DATE LIST}

- Lab codes: GrN - conventional (radiometry); GrA - AMS (accelerator mass spectrometry).

- Errors are all $1 \sigma$; measurements (BP) and calibrations (cal BCE) are rounded to the nearest 5, except for high-precision conventional measurements $(1 \sigma<15 \mathrm{BP})$.

- Dates are calibrated using IntCal04 (Reimer et al. 2004). Very small probabilities in the calibrated age distribution are ignored. 


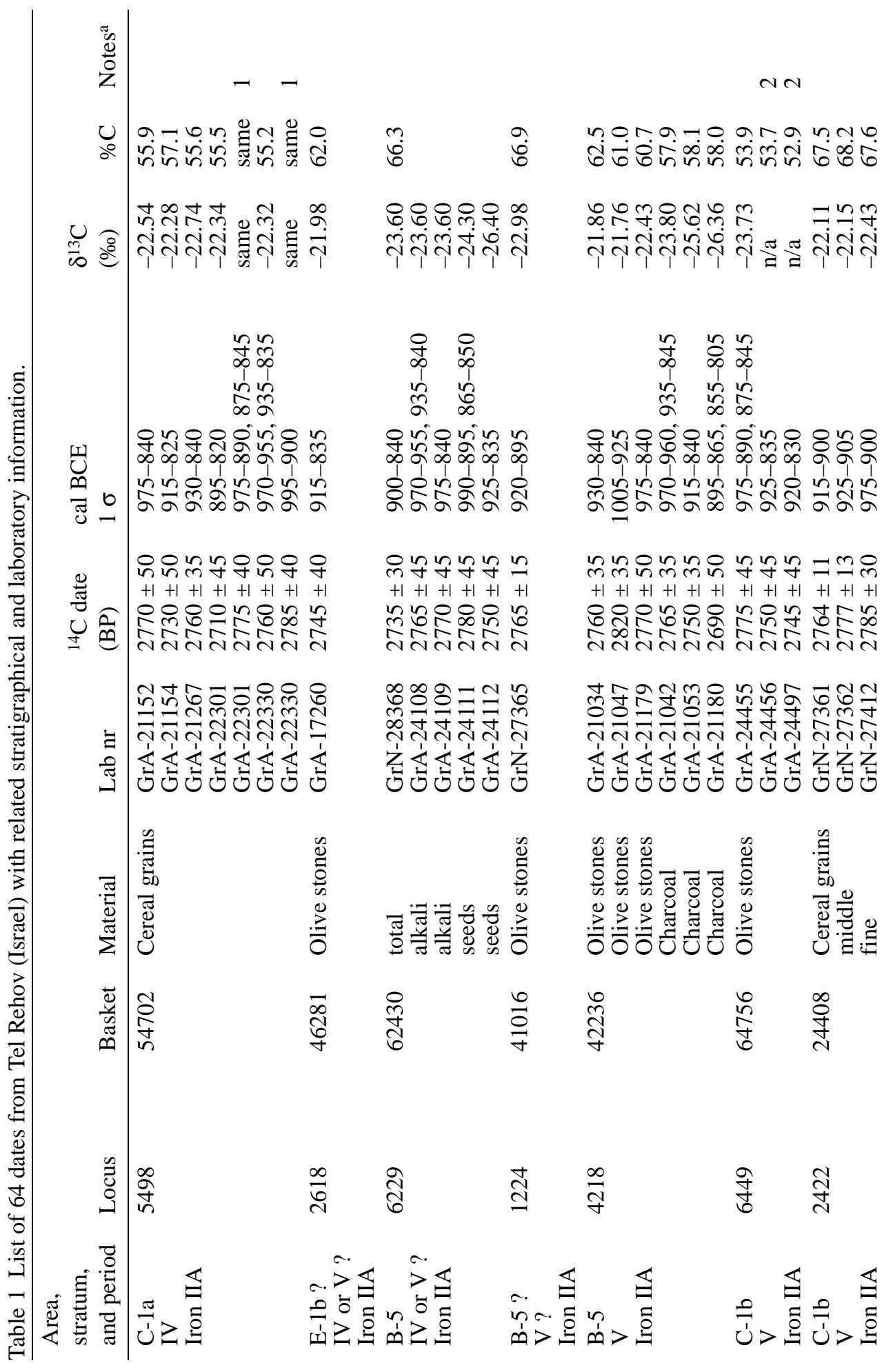




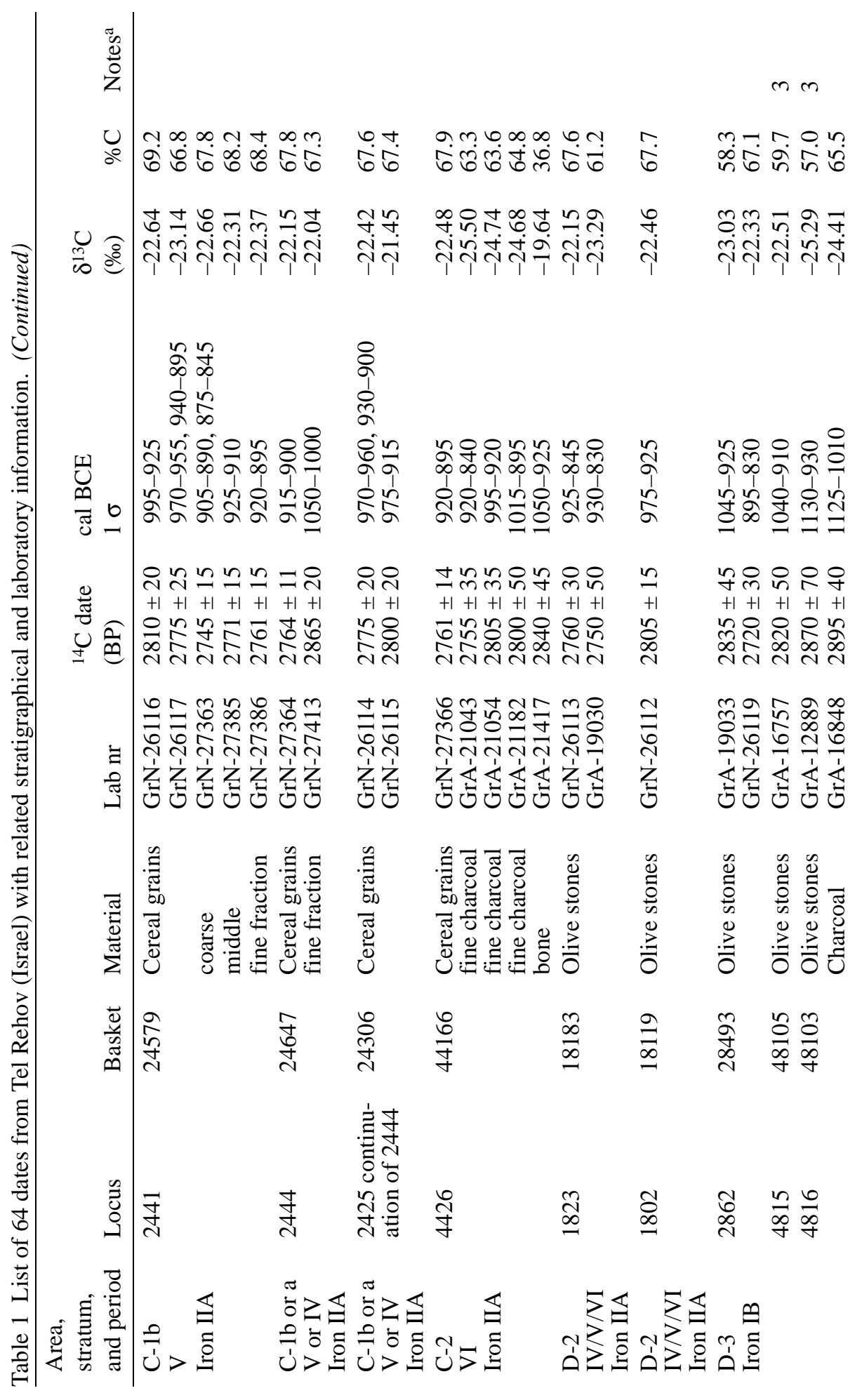




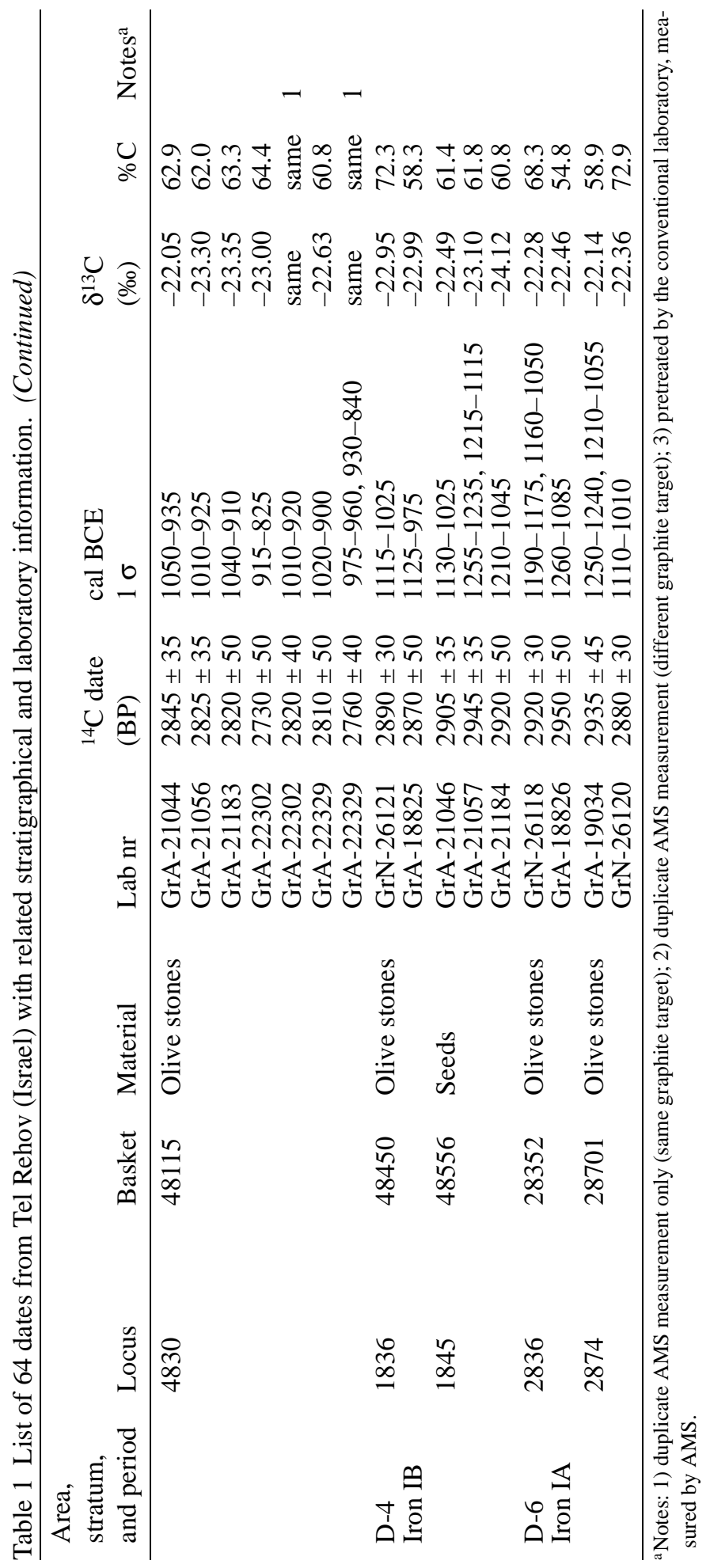




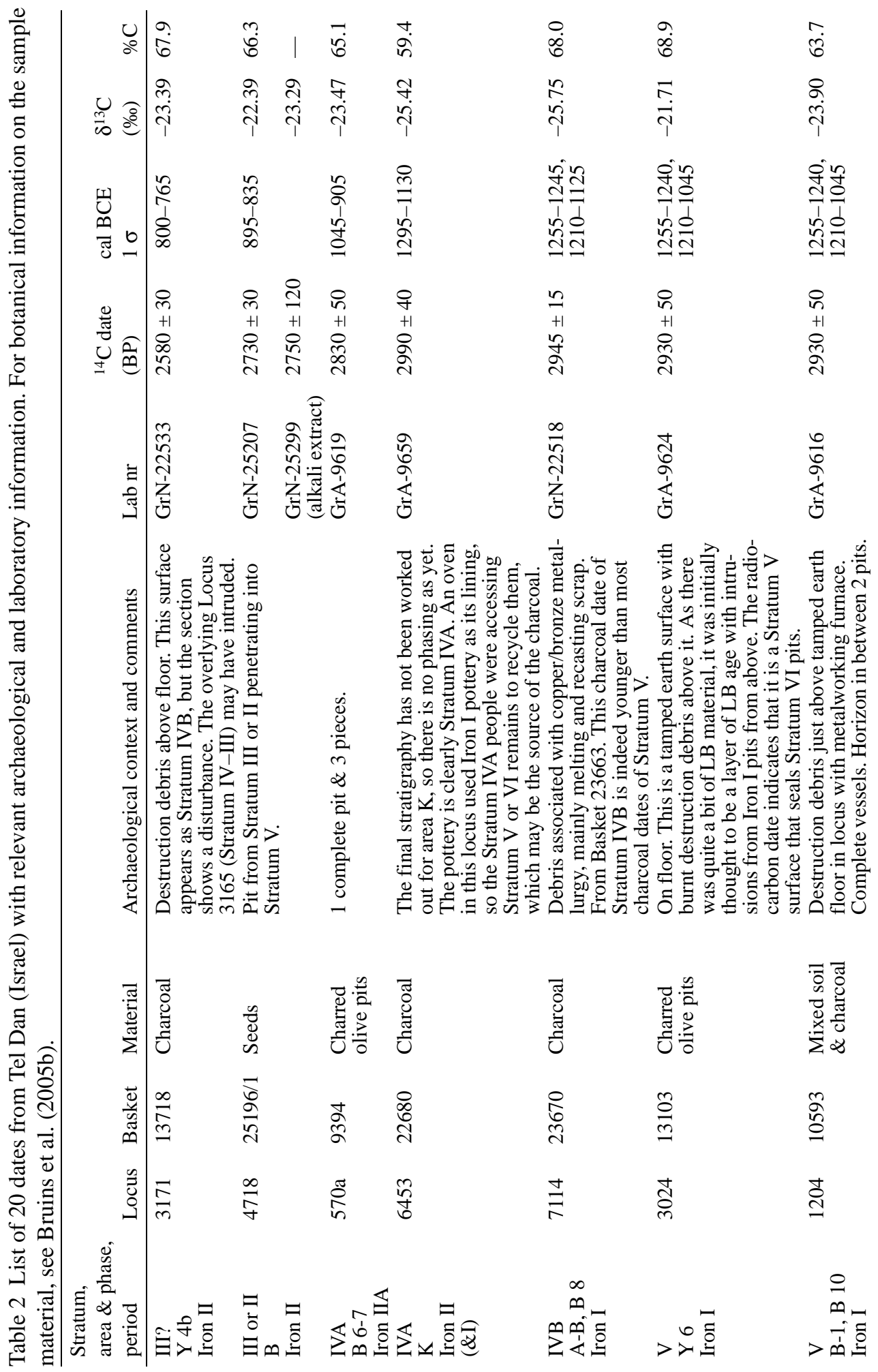




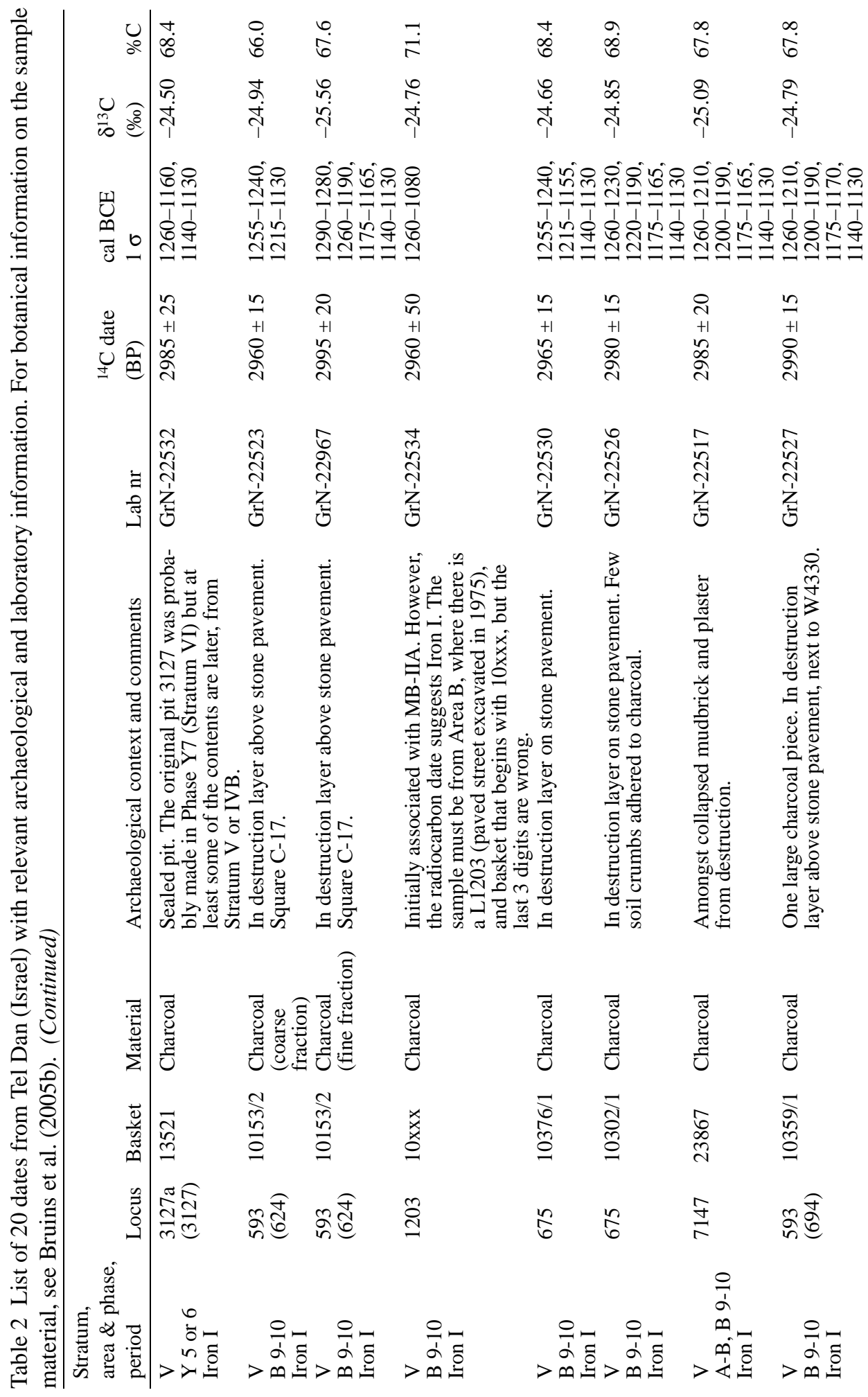




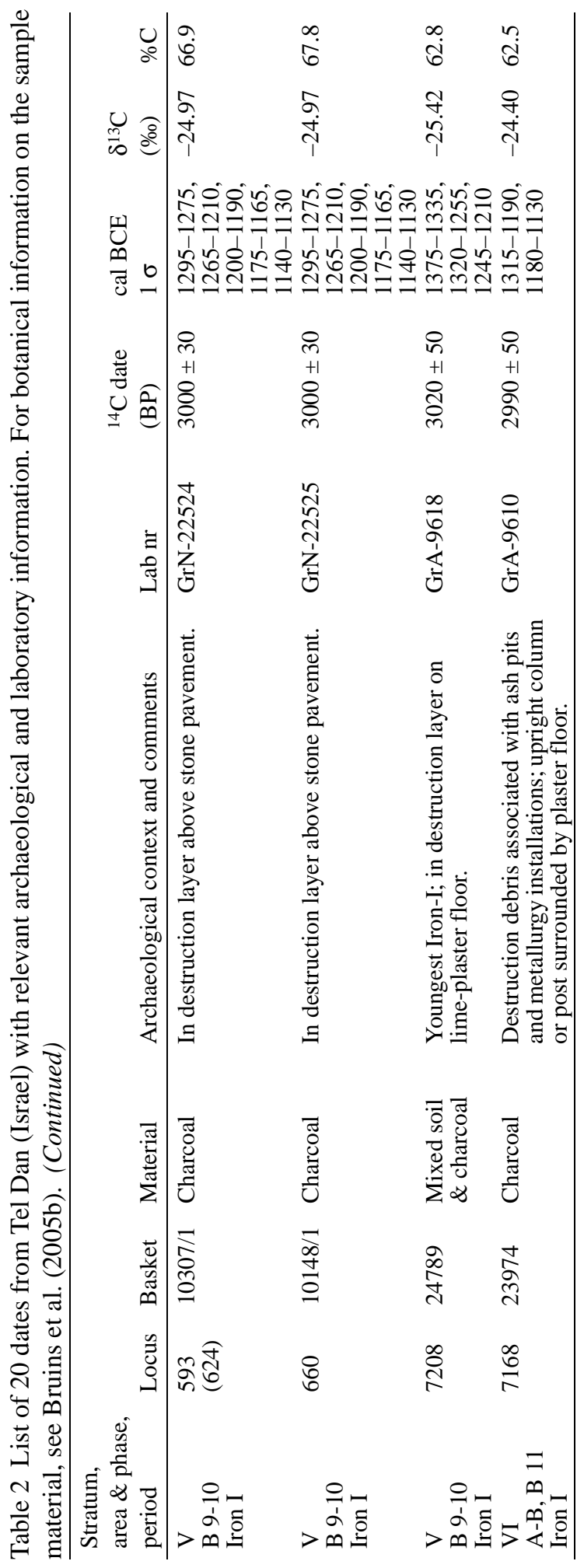


Table 3 List of dates for the fortresses at Tell el-Qudeirat, northeastern Sinai, Egypt (partly based on Bruins and van der Plicht 2005).

\begin{tabular}{lllllll}
\hline Sample & Material & $\begin{array}{l}\text { Lab nr } \\
(\mathrm{GrN}-)\end{array}$ & $\begin{array}{l}{ }^{14} \mathrm{C} \text { date } \\
(\mathrm{BP})\end{array}$ & $\begin{array}{l}\text { cal BCE } \\
1 \sigma\end{array}$ & $\begin{array}{l}\delta^{13} \mathrm{C} \\
(\% \circ)\end{array}$ & $\% \mathrm{C}$ \\
\hline $\begin{array}{l}\text { Upper Fortress } \\
\text { grains in jar }\end{array}$ & $\begin{array}{l}\text { Charred cereal } \\
\text { grains }\end{array}$ & 15551 & $2515 \pm 15$ & $765-750,685-665,635-595$ & -21.93 & 68.1 \\
$\begin{array}{l}\text { Upper Fortress } \\
\text { destruction layer }\end{array}$ & $\begin{array}{l}\text { Charred organic } \\
\text { Middle Fortress }\end{array}$ & 12329 & $2535 \pm 50$ & $790-745,685-665,645-550$ & -22.89 & 65.0 \\
$\begin{array}{l}\text { Charred organic } \\
\text { destruction layer }\end{array}$ & 11948 & $2740 \pm 110$ & $1025-800$ & -23.42 & 62.5 \\
$\begin{array}{l}\text { Lower Fortress } \\
\text { destruction layer }\end{array}$ & Charred organic & 12330 & $2930 \pm 30$ & $1205-1055$ & -22.53 & 63.6 \\
\hline
\end{tabular}

Table 4 List of dates for wadi east, terrace 12, Horvat Haluqim, Israel (partly based on Bruins and van der Plicht 2005, 2007).

\begin{tabular}{|c|c|c|c|c|c|c|}
\hline Sample & Material & $\begin{array}{l}\text { Lab nr } \\
\text { (GrA-) }\end{array}$ & $\begin{array}{l}{ }^{14} \mathrm{C} \text { date } \\
\text { (BP) }\end{array}$ & $\begin{array}{l}\text { cal BCE } \\
1 \sigma\end{array}$ & $\begin{array}{l}\delta^{13} \mathrm{C} \\
(\% 0)\end{array}$ & $\% \mathrm{C}$ \\
\hline $\begin{array}{l}\text { Area } 1 \\
\text { level a }\end{array}$ & Charred organic matter & 12448 & $2590 \pm 60$ & $\begin{array}{l}825-750,685-665 \\
640-590\end{array}$ & -17.75 & 53.9 \\
\hline $\begin{array}{l}\text { Area } 1 \\
\text { level b }\end{array}$ & Bone sheep/goat & 14398 & $2860 \pm 40$ & $1110-975$ & -20.00 & 35.6 \\
\hline $\begin{array}{l}\text { Area } 5 \\
\text { II Ah } \\
34 \mathrm{~cm}\end{array}$ & Charred organic matter & 27533 & $2840 \pm 40$ & 1045-930 & -23.71 & 45.0 \\
\hline $\begin{array}{l}\text { Area } 5 \\
\text { II Ah } \\
40 \mathrm{~cm}\end{array}$ & Charred organic matter & 27674 & $2930 \pm 50$ & $1210-1050$ & -11.16 & 46.0 \\
\hline $\begin{array}{l}\text { Area } 5 \\
\text { III AhC } \\
41 \mathrm{~cm}\end{array}$ & Charred organic matter & 27535 & $2875 \pm 40$ & $1120-1000$ & -11.97 & 22.7 \\
\hline $\begin{array}{l}\text { Area } 5 \\
\text { III AhC } \\
45 \mathrm{~cm}\end{array}$ & Charred organic matter & 27536 & $2970 \pm 40$ & $1260-1130$ & -21.03 & 58.3 \\
\hline $\begin{array}{l}\text { Area } 5 \\
\text { III AhC } \\
50 \mathrm{~cm}\end{array}$ & Charred organic matter & 27648 & $3240 \pm 30$ & $1530-1455$ & -23.53 & 65.6 \\
\hline
\end{tabular}

Table 5 List of ${ }^{14} \mathrm{C}$ dates from Khirbet en-Nahas (Jordan).

\begin{tabular}{|c|c|c|c|c|c|c|c|}
\hline Stratum & Sample & $\begin{array}{l}\text { Dated } \\
\text { fraction }\end{array}$ & $\begin{array}{l}\text { Lab nr } \\
(\mathrm{GrA}-)\end{array}$ & $\begin{array}{l}{ }^{14} \mathrm{C} \text { date } \\
\text { (BP) }\end{array}$ & $\begin{array}{l}\text { cal BCE } \\
1 \sigma\end{array}$ & $\begin{array}{l}\delta^{13} \mathrm{C} \\
(\% \circ)\end{array}$ & $\% \mathrm{C}$ \\
\hline A-2A & $\begin{array}{l}\text { L.21-B.1069 } \\
\text { ash and slag layer }\end{array}$ & charcoal & 25311 & $2710 \pm 35$ & $895-825$ & -12.08 & 65.8 \\
\hline $\mathrm{A}-2 \mathrm{~A}$ & L.21-B.1419 & charcoal & 25312 & $2670 \pm 35$ & $\begin{array}{l}890-885 \\
835-800\end{array}$ & -10.88 & 68.8 \\
\hline A-2A & L.21-B.1458 & kaline & 25334 & $2910 \pm 50$ & $1210-1010$ & -24.61 & 31.5 \\
\hline $\mathrm{A}-2 \mathrm{~B}$ & $\begin{array}{l}\text { L.74-B.1659 } \\
\text { copper industrial waste }\end{array}$ & & 25314 & $2705 \pm 35$ & $895-825$ & -26.69 & 63.4 \\
\hline$A-2 B$ & L.74-B.1655 & & 25315 & $2705=$ & & -25.50 & 66.6 \\
\hline$A-2 B$ & L.74-B.1642 & charcoal & 25316 & $2815 \pm 40$ & $1005-905$ & -24.96 & 44.0 \\
\hline
\end{tabular}


Table 5 List of ${ }^{14} \mathrm{C}$ dates from Khirbet en-Nahas (Jordan). (Continued)

\begin{tabular}{|c|c|c|c|c|c|c|c|}
\hline Stratum & Sample & $\begin{array}{l}\text { Dated } \\
\text { fraction }\end{array}$ & $\begin{array}{l}\text { Lab nr } \\
\text { (GrA-) }\end{array}$ & $\begin{array}{l}{ }^{14} \mathrm{C} \text { date } \\
(\mathrm{BP})\end{array}$ & $\begin{array}{l}\text { cal BCE } \\
1 \sigma\end{array}$ & $\begin{array}{l}\delta^{13} \mathrm{C} \\
(\% o)\end{array}$ & $\% \mathrm{C}$ \\
\hline A-3 & $\begin{array}{l}\text { L. } 89-B .1840 \\
\text { red sediment bel. indus. }\end{array}$ & charcoal & 25318 & $2920 \pm 35$ & $1210-1045$ & -26.01 & 44.0 \\
\hline A-3 & L.89-B.1911 & alkaline & 25354 & $2880 \pm 50$ & $\begin{array}{l}1185-1180 \\
1125-945\end{array}$ & -12.24 & 58.4 \\
\hline A-3 & $\begin{array}{l}\text { L.53-B.1332 } \\
\text { solid ash layer }\end{array}$ & charcoal & 25321 & $2660 \pm 40$ & $835-795$ & -23.76 & 64.3 \\
\hline A-3 & $\begin{array}{l}44 \\
\text { own layer }\end{array}$ & charcoal & 25322 & $2680 \pm 40$ & $\begin{array}{l}895-875 \\
835-800\end{array}$ & -25.45 & 61.7 \\
\hline A-4A & 9 & charcoal & 25320 & $2710 \pm 35$ & $895-825$ & -25.34 & 55.5 \\
\hline S-1 & $\begin{array}{l}70 \\
e \text { am. of slag }\end{array}$ & charcoal & 25324 & $2720 \pm 35$ & $895-830$ & -23.57 & 61.9 \\
\hline S-1 & and & charcoal & 25325 & $2700 \pm 35$ & $895-810$ & -11.99 & 61.0 \\
\hline S-1 & 1. and & charcoal & 25326 & $2735 \pm 35$ & $900-835$ & -24.57 & 65.9 \\
\hline S-1 & L.317-B.6383 & charcoal & 25328 & $2670 \pm 35$ & $\begin{array}{l}890-885 \\
835-800\end{array}$ & -26.12 & 58.9 \\
\hline S-1 & & arcoal & & $2795 \pm 45$ & 1000 & -26.18 & 57.4 \\
\hline S-2A & & & 25329 & 2705 & & -27.38 & 66.1 \\
\hline$S-2 A$ & & al & 25331 & $2820 \pm 35$ & 1005 & -10.62 & 78.1 \\
\hline$S-2 A$ & ide str. & charcoal & 25332 & $2715 \pm 40$ & $895-830$ & -23.60 & 61.6 \\
\hline$S-2 A$ & $\begin{array}{l}\text { L. } 340-\text { B. } 7594 \\
\text { silty sed. bel. and } \\
\text { w/ collapse }\end{array}$ & charcoal & 25343 & $2720 \pm 45$ & $900-825$ & -10.12 & 54.9 \\
\hline$S-2 B$ & $\begin{array}{l}.7524 \\
\text { l. outside str. }\end{array}$ & charcoal & 25344 & $2770 \pm 45$ & $970-835$ & -22.05 & 63.5 \\
\hline$S-2 B$ & $\begin{array}{l}\text { L. } 338 \text {-B. } 7418 \\
\text { surface inside stucture }\end{array}$ & charcoal & 25345 & $2780 \pm 45$ & $995-840$ & -25.68 & 59.8 \\
\hline$S-3$ & $\begin{array}{l}\text { L. } 342-B .7660 \\
\text { slag layer }\end{array}$ & charcoal & 25353 & $2820 \pm 50$ & 1040-900 & -24.66 & 71.6 \\
\hline$S-3$ & $\begin{array}{l}\text { L.344-B. } 7621 \\
\text { slag layer/surface }\end{array}$ & charcoal & 25347 & $2830 \pm 45$ & $1045-915$ & -25.46 & 66.2 \\
\hline S-4 & $\begin{array}{l}\text { L. } 346-\text { B. } 7667 \\
\text { silty sed. above surface }\end{array}$ & charcoal & 25348 & $2770 \pm 45$ & $970-835$ & -24.97 & 61.1 \\
\hline S-4 & $\begin{array}{l}\text { L. } 347-B .7659 \\
\text { fill above surface }\end{array}$ & charcoal & 25349 & $2790 \pm 45$ & $1000-865$ & -26.21 & 63.0 \\
\hline S-4 & $\begin{array}{l}\text { L.353-B.7738 } \\
\text { surface }\end{array}$ & charcoal & 25352 & $2800 \pm 45$ & 1005-900 & -25.76 & 60.3 \\
\hline
\end{tabular}


Table 6 List of ${ }^{14} \mathrm{C}$ dates from Latium Vetus (central Italy).

\begin{tabular}{|c|c|c|c|c|c|c|}
\hline imple & Material & Lab nr & ${ }^{4} \mathrm{C}$ (BP) & & $\% \mathrm{C}$ & cal BCE \\
\hline $\begin{array}{l}\text { Late Bronze Age } \\
\text { Nettuno, P13 } \\
\text { Nettuno, P13 } \\
\text { QTS, hearth sample } 1\end{array}$ & $\begin{array}{l}\text { collagen } \\
\text { collagen } \\
\text { seeds }\end{array}$ & $\begin{array}{l}\text { GrA-22092 } \\
\text { GrA-22090 } \\
\text { GrA-27848 }\end{array}$ & $\begin{array}{l}3005 \pm 45 \\
2945 \pm 45 \\
2985 \pm 40\end{array}$ & & $\begin{array}{l}15.0 \\
23.3 \\
53.5\end{array}$ & \\
\hline $\begin{array}{l}\text { Tombs mainly from Latial pe } \\
\text { Foro di Cesare, T1 } \\
\text { S. Palomba, burial } 1 \\
\text { Trigoria, burial } 3 \\
\text { S. Palomba, burial } 2 \\
\text { Roma, Quadrato, T.2 } \\
\text { Roma, Quadrato, T.1 } \\
\text { Roma, Campidoglio, Giardino } \\
\text { Romano Tomb 6 } \\
\text { Foro di Cesare, T.2 }\end{array}$ & $\begin{array}{l}\text { apatite } \\
\text { apatite } \\
\text { apatite } \\
\text { charcoal } \\
\text { apatite } \\
\text { apatite } \\
\text { seeds }\end{array}$ & $\begin{array}{l}\text { GrA-16432 } \\
\text { GrA-27028 } \\
\text { GrA-27025 } \\
\text { GrA-27847 } \\
\text { GrA-16423 } \\
\text { GrA-16411 } \\
\text { GrA-32904 }\end{array}$ & $\begin{array}{l}2920 \pm 60 \\
2875 \pm 35 \\
2870 \pm 35 \\
2865 \pm 40 \\
2820 \pm 50 \\
2810 \pm 50 \\
2800 \pm 30\end{array}$ & $\begin{array}{l}-27.10 \\
-22.69\end{array}$ & 59.7 & $\begin{array}{l}1250-1025 \\
1115-1005 \\
1115-1000 \\
1115-980 \\
1040-910 \\
1040-900\end{array}$ \\
\hline $\begin{array}{l}\text { Tomb } 63 \text { (Latial phase IIB1) } \\
\text { Tomb } 86 \text { (Latial phase IIB1) } \\
\text { Tomb } 85 \\
\text { Tomb } 71 \text { (Latial phase IIA2) } \\
\text { Tomb } 25 \\
\text { Tomb } 40\end{array}$ & $\begin{array}{l}\text { collagen } \\
\text { collagen } \\
\text { collagen } \\
\text { collagen } \\
\text { collagen } \\
\text { collagen } \\
\text { collagen }\end{array}$ & & & & $\begin{array}{l}25.8 \\
32.8 \\
47.7 \\
20.0 \\
40.6 \\
41.9 \\
43.7\end{array}$ & \\
\hline $\begin{array}{l}\text { Fidene hut } \\
\text { Fidene hut } \\
\text { Fidene hut } \\
\text { Fidene hut } \\
\text { Fidene hut }\end{array}$ & $\begin{array}{l}\text { charcoal } \\
\text { charcoal } \\
\text { charcoal } \\
\text { seeds } \\
\text { seeds }\end{array}$ & $\begin{array}{l}\text { GrN-20127 } \\
\text { GrN-20125 } \\
\text { GrN-20126 } \\
\text { GrA-5007 } \\
\text { GrA-5008 }\end{array}$ & $\begin{array}{l}2820 \pm 50 \\
2800 \pm 50 \\
2790 \pm 50 \\
2770 \pm 50 \\
2760 \pm 50\end{array}$ & $\begin{array}{l}-25.47 \\
-25.06 \\
-25.69 \\
-23.79 \\
-24.80\end{array}$ & $\begin{array}{l}68.9 \\
65.8 \\
65.5 \\
58.6 \\
60.8\end{array}$ & $\begin{array}{r}1040-910 \\
1015-895 \\
1005-895 \\
975-840 \\
970-835\end{array}$ \\
\hline $\begin{array}{l}\text { hut feature II, fireplace } \\
\text { Hut VI, lowest level }\end{array}$ & $\begin{array}{l}\text { charcoal } \\
\text { charcoal }\end{array}$ & $\begin{array}{l}\text { GrN-11669 } \\
\text { GrN-16466 }\end{array}$ & $\begin{array}{l}2670 \pm 30 \\
2620 \pm 30\end{array}$ & & $\begin{array}{l}65.1 \\
64.4\end{array}$ & $\begin{array}{l}835-805 \\
815-795\end{array}$ \\
\hline
\end{tabular}

Table 7 List of ${ }^{14} \mathrm{C}$ dates from Celano (central Italy). WMD = wiggle-match dating.

\begin{tabular}{lllll}
\hline Sample and material & Lab nr & ${ }^{14} \mathrm{C}(\mathrm{BP})$ & $\delta^{13} \mathrm{C}(\% \circ)$ & $\% \mathrm{C}$ \\
\hline Celano Tomb 4, Final Bronze Age & & & & \\
Celano, Tomb 4, rings 1-10 & GrN-30007 & $2970 \pm 25$ & -27.42 & 55.7 \\
Celano, Tomb 4, rings 40-50 & GrN-30008 & $2920 \pm 25$ & -27.04 & 53.4 \\
Celano, Tomb 4, rings 80-90 & GrN-30009 & $2935 \pm 25$ & -26.50 & 56.1 \\
Celano, Tomb 4, rings 110-120 & GrN-30010 & $2915 \pm 25$ & -26.97 & 56.1 \\
Celano, Tomb 4, rings 150-168 & GrN-30011 & $2900 \pm 25$ & -26.03 & 53.3 \\
WMD: youngest ring dated to 1040 BC & & & & \\
Celano Tomb 5, Final Bronze Age & & & & \\
Celano, Tomb 5, rings 1-10 & GrN-28912 & $2950 \pm 30$ & -25.71 & 56.7 \\
Celano, Tomb 5, rings 11-20 & GrN-28913 & $2910 \pm 30$ & -26.01 & 59.2 \\
Celano, Tomb 5, rings 21-30 & GrN-28914 & $2835 \pm 30$ & -26.89 & 57.8 \\
Celano, Tomb 5, rings 31-40 & GrN-28915 & $2835 \pm 40$ & -26.92 & 59.5 \\
Celano, Tomb 5, rings 41-50 & GrN-28916 & $2845 \pm 40$ & -26.69 & 56.1 \\
WMD: youngest ring dated to 1018 BC \pm 15 yr & & & \\
\hline
\end{tabular}


Table 8 List of ${ }^{14} \mathrm{C}$ dates from Huelva (southern Spain).

\begin{tabular}{lllllll}
\hline & & ${ }^{14} \mathrm{C}$ date & Error & & & cal BCE \\
Sample & Lab nr & BP & \pm & $\delta^{13} \mathrm{C}(\%)$ & $\% \mathrm{C}$ & $1 \sigma$ \\
\hline Huelva 1 & GrN-29511 & 2745 & 25 & -19.98 & 49.8 & $905-840$ \\
Huelva 2 & GrN-29512 & 2775 & 25 & -20.94 & 41.7 & $970-955,935-895$ \\
Huelva 3 & GrN-29513 & 2740 & 25 & -20.08 & 50.2 & $905-840$ \\
Average & & 2755 & 15 & & & $915-895,865-850$ \\
\hline
\end{tabular}

Table 9 List of ${ }^{14} \mathrm{C}$ dates from Carthage (north Africa).

\begin{tabular}{lllllll}
\hline Sample & Lab nr & Age BP & $\begin{array}{l}\text { Error } \\
\pm\end{array}$ & $\begin{array}{l}\delta^{13} \mathrm{C} \\
(\%)\end{array}$ & $\%$ Cal BCE \\
\hline Hamburg excavations & & & & & \\
Ka93-181 & GrN-26090 & 2650 & 30 & -20.40 & 45.9 & $825-795$ \\
Ka93-183 & GrN-26091 & 2710 & 30 & -20.36 & 47.4 & $895-865,850-825$ \\
Ka93-220 & GrN-26093 & 2640 & 50 & -21.00 & 47.7 & $840-780$ \\
Ka93-499 & GrN-26094 & 2660 & 30 & -20.22 & 41.7 & $830-800$ \\
Average & & 2670 & 20 & & & $825-805$ \\
Gent excavations & & & & & & \\
Carthago 4465 & GrA-28584 & 2620 & 35 & -19.57 & 45.2 & $815-785$ \\
Carthago 4463 & GrA-28581 & 2590 & 30 & -18.09 & 42.1 & $800-775$ \\
Carthago 4458 & GrN-29278 & 2590 & 25 & -18.83 & 43.8 & $800-780$ \\
BM02/7239 & GrA-27159 & 2580 & 35 & -19.14 & 39.6 & $800-765$ \\
BM02/7239 & GrA-27169 & 2565 & 35 & -18.71 & 38.7 & $800-755,680-670$ \\
Duplo & & & & & & \\
BM03/3338 & GrA-27165 & 2550 & 35 & -20.80 & 38.3 & $795-750,685-665,630-595$ \\
BM03/3338 & GrA-27171 & 2570 & 35 & -20.17 & 38.9 & $800-760,680-670$ \\
Duplo & & & & & & \\
BM03/3339 & GrA-27167 & 2520 & 35 & -20.28 & 39.2 & $775-745,685-665,645-555$ \\
BM03/3339 & GrA-27168 & 2535 & 40 & -19.84 & 36.1 & $790-745,685-665,640-565$ \\
Duplo & & & & & & \\
Carthago 4459 & GrN-29279 & 2520 & 25 & -19.73 & 50.4 & $770-750,685-665,640-570$ \\
Carthago 4461 & GrN-29281 & 2520 & 25 & -19.27 & 44.2 & $770-750,685-665,640-570$ \\
Carthago 4460 & GrN-29280 & 2520 & 40 & -20.68 & 37.9 & $780-745,685-665,645-550$ \\
BM03/5380 & GrA-27131 & 2505 & 40 & -19.06 & 29.4 & $765-735,690-545$ \\
\hline
\end{tabular}

